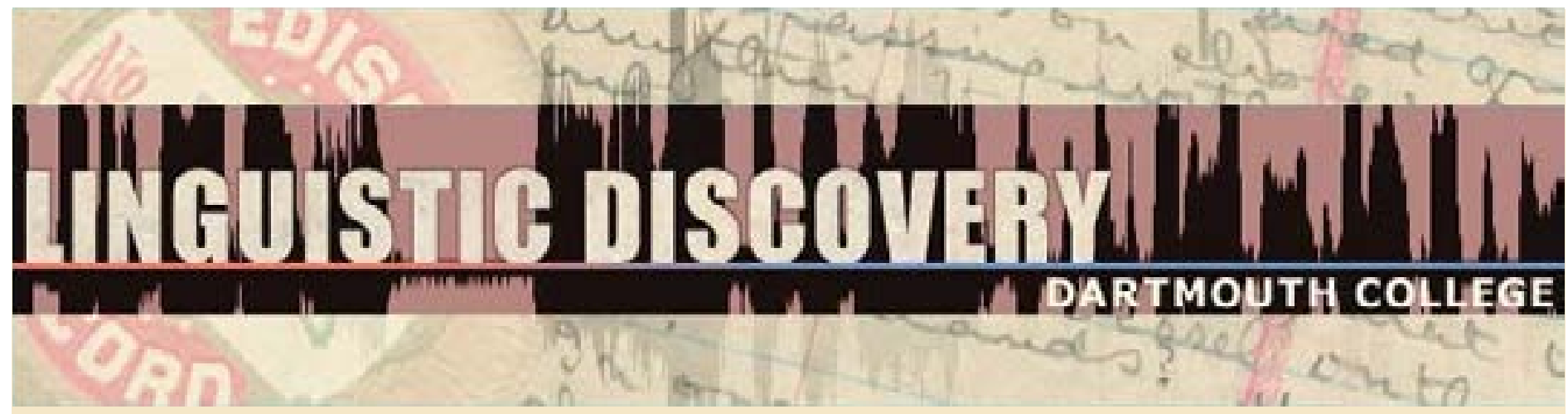

\begin{tabular}{|l|}
\hline Volume 9 \\
Issue 1 \\
2011 \\
\hline
\end{tabular}

\title{
The Intonation Patterns of Interrogatives in Persian
}

Nima Sadat-Tehrani

University of Manitoba

doi: 10.1349/PS1.1537-0852.A.389

url: http://journals.dartmouth.edu/cgi-bin/WebObjects/ Journals.woa/1/xmlpage/1/article/389 


\title{
The Intonation Patterns of Interrogatives in Persian
}

\author{
Nima Sadat-Tehrani
}

This paper investigates the intonational properties of different types of interrogatives in Persian in the framework of the autosegmental-metrical theory of intonation. The structures studied are different types of yes/no questions, WH-questions, tag questions, and echo questions. The results, which are based on a total of nearly 400 read utterances recorded in laboratory conditions, show that the Persian Accentual Phrase (AP) with the pitch accent $(L+) H^{*}$ is present in all question types. Yes/no questions, whose accentuation follows the same constraints as declaratives, are characterized by a high Intonational Phrase boundary tone $(H \%)$, and have a greater pitch excursion and more final lengthening on the last AP than declaratives. The inclusion of particles and words such as aya, mæge, and hič in the question adds an AP but does not change the core intonation pattern. In (multiple) WH-questions, which have a falling intonation similar to declaratives, the (final) WH-word is the nuclear pitch accent, followed by the deaccentuation of the upcoming elements. Echo questions end high and the boundary tone of their final AP can be either high or low. Contrastive focus APs are higher and longer than ordinary APs and deaccent what follows, even if it includes a WH-word.

\section{Introduction}

This paper is an attempt at discovering the intricacies of the intonation patterns of different types of interrogative sentences in Modern Conversational Persian, hereafter referred to as Persian, spoken in Tehran, the capital city of Iran. This is done with the help of 5 native speakers who read a total of 392 utterances designed for this paper and composed of the following question types: yes/no questions (YNQs) (with and without a question particle aya), leading YNQs (with the particle mage), YNQs with the adverb hič, tag questions, single and multiple WH-questions (WHQs), echo questions, and contrastive focus YNQs and WHQs. Two of the 5 speakers were female and three were male, one of the males being the author. They had an age range of 26-41 and had lived in Iran all their life before moving to Canada 3 to 6 years ago. They had been using Persian in some of their daily communications since they left Iran. The speakers all spoke the dialect under study without any foreign accent and were all consistent as far as the production of different question types was concerned, so they were considered to be representative of the general population.

It must be noted that intonational studies make use of different types of speech data, including read speech, spontaneous speech, retelling of a story (Grabe 1998), dialogue games (Krahmer and Swerts 2001), and map tasks (Grice and Savino 2003). It may be argued that using a linguistic corpus of spontaneous speech will yield more reliable results in language studies; however, there are several arguments defending the kind of data collection used in the present research. The first is the nature of the work itself. In determining the intonation patterns of interrogatives, the researcher must have a pool of all the question types that she wants to study. This is made possible by way of designing a set of data; it is practically impossible to find all the utterances appropriate for an undertaking of this sort in a given corpus. The second argument is an empirical one. Lickley et al. (2005) measure the alignment of lows in Dutch falling-rising questions with two sets of data, read data and map task dialogs, i.e., conversations where the questioner requests information from a partner regarding the different locations on a map. Lickley and colleagues reach the same results from the two sets and conclude that lab speech can 
be used in experimental research concerning phonological and phonetic issues. The third argument addresses the problem of decontextualization in read speech: that lab speech lacks context. This is not the case with the present work. All of the sentences that were in any way ambiguous or that needed a specific context (including contrastively-focused sentences) were explained to the speakers and an appropriate pronunciation was elicited. ${ }^{1}$ The present paper uses read speech as a point of departure for such a study on Persian, and it is hoped that future research continues this undertaking with the help of other types of data.

The recordings were done in multiple sessions. The sentences were presented to the speakers on cue cards in random order, and each speaker read each sentence once. The productions were recorded by a Marantz PMD660 professional digital voice recorder using a Shure KSM109 cardioid condenser microphone placed at a fixed distance of about $40 \mathrm{~cm}$ from the speaker. The recordings were input to the Praat software (Boersma and Weenink 2010). The data were read in the default pronunciation unless a particular pronunciation was required (as in contrastive focus contexts) in which case a short context was provided to elicit the intended meaning.

The main goals of this paper are twofold: first, to shed some light on a corner of an intonationally underdocumented language, and second and more general, to take a step in enriching the typological studies of intonation by adding another language to the already existing ones, hence to pave the way to a more refined theory of intonation by comparing and contrasting a greater number of languages.

The work is done in the framework of the autosegmental-metrical (AM) theory of intonation, a term coined by Ladd (1996/2008). This theory is built on works such as Beckman and Pierrehumbert (1986), Bruce (1977), Pierrehumbert (1980), and Pierrehumbert and Beckman (1988) and has since motivated much research, e.g., Arvaniti et al. (2006), Frota (2002a), Grice et al. (2000), Hayes and Lahiri (1991), Prieto et al. (1995), and Welby (2006), to name only a few. The AM theory has a phonological approach to intonation and views an intonation contour as a string of $\mathrm{H}(\mathrm{igh})$ and $\mathrm{L}(\mathrm{ow})$ tones. These tonal events are in the form of pitch accents (e.g., $\mathrm{H}^{*}$ ) and edge tones (e.g., $\mathrm{H} \%$ ) and associate with points in the segmental string, and transitions between these points are phonologically irrelevant. The tones are aligned in certain ways against the segmental string, for instance in Northern and Southern German, the alignment of $\mathrm{H}$ in prenuclear rises is at the onset of the poststress vowel (Atterer and Ladd 2004), or in Persian, the $\mathrm{L}$ is aligned with the consonant preceding the stressed vowel of the Accentual Phrase (SadatTehrani 2009).

The organization of the paper is as follows. Section 2 provides an overview of lexical stress, prosodic system, and the location of nuclear accent in the Persian language. Section 3 contains the details of the interrogative intonation in Persian. Section 4 concludes the paper.

\section{Background on Persian: Stress, Prosodic Structure, and Nuclear Pitch Accent}

Persian is an Iranian SOV language (Dabir-Moghaddam 1982, Karimi 2005) belonging to the Indo-Iranian subbranch of the eastern branch of the Indo-European language family. This language is classified as a "stress-accent" language along with English, German, Dutch, Greek, Italian, Spanish, European Portuguese, Lebanese Arabic, and Bininj Gun-wok (a Northern Australian language) by Jun (2005). She defines such languages as those in which phonetic

\footnotetext{
${ }^{1}$ For more general arguments in favor of lab speech, see Xu (2010).
} 
factors result in more prominence of a certain syllable compared to other syllables of a word. Pitch accents in Persian are associated with the lexically stressed syllables (Eslami and Bijankhan 2002). Location of Persian lexical stress has been discussed in the following works among others: Kahnemuyipour (2003), Lazard (1992), Mahootian (1997), Parmoon (2006), Same'i (1996), and Vahidian-Kamyar (2001). A summary of Persian stress rules includes the following. For nouns (kasé 'bowl'), adjectives (laqár 'thin'), and most adverbs (arúm 'quietly'), the stress is word-final. Polymorphemic nouns, adjectives, and adverbs show the same behaviour, as exemplified in (1). ${ }^{2}$

(1) a. kase-há

bowl-PL

'bowls'

b. laqær-tǽr

thin-COMPARATIVE

'thinner'

Verbs are stressed on the final syllable of the main constituent. Example (2) is illustrative.

(2) pors-íd-æn.

ask-PST-3PL

'They asked.'

In (2), pors-id (the past stem) is the main constituent and -aen is the person ending. The negative marker $n e-/ n c e-$, the subjunctive/imperative prefix $b e$-, and the durative prefix $m i$ - attract the stress in verbs (nóe-pors-id-an 'They didn't ask'). Compound verbs, which consist of a nonverbal element and a verb combined to denote a single predicate (Dabir-Moghaddam 1997, Folli et al. 2005, and Ghomeshi and Massam 1994 among others), have their stress on the nonverbal element, as illustrated in (3).

(3) zanú+zæd.

knee+hit.PST.3SG

'S/he kneeled.'

Within the framework of the AM theory of intonation, a few works have been done on Persian intonation, which include a Ph.D. dissertation in Persian (Eslami 2000), an M.S. thesis (Mahjani 2003), a UCLA Field Methods course manuscript (Jun et al. 2003) containing a part on questions (Esposito and Barjam 2007), and a Ph.D. dissertation (Sadat-Tehrani 2007). The Accentual Phrase (AP) is proposed as the smallest unit of intonation in Persian, with the pitch accent $\mathrm{L}^{+\mathrm{H}^{*}}$ associating with the stressed syllable. This pitch accent is realized as $\mathrm{H}^{*}$ for initially-stressed words and monosyllabic content words. An AP is normally composed of a content word plus its possible clitics, but sometimes in long APs the L can form a low plateau extending leftward from the $\mathrm{H}^{*}$ over several unstressed syllables which can belong to more than one content word. An

\footnotetext{
${ }^{2}$ The abbreviations used in this paper are: $\mathrm{CL}=$ clitic; $\mathrm{DEF}=$ definite; $\mathrm{DUR}=$ durative; $\mathrm{EZ}=$ the Ezafe vowel; IND=indefinite; NEG=negation; PL=plural; PRS=present; PST=past; PTC=particle; PTCP=participle; $\mathrm{QP}=$ question particle; $\mathrm{RA}=$ specificity marker; $\mathrm{SG}=$ singular; ' + ' in the examples separates the two parts of a compound verb.
} 
AP is marked by a high (h) or low (l) boundary tone at the right edge. The low boundary tone is used for the last (nuclear) AP in most simple monoclausal sentences and the prenuclear APs all have a high boundary tone ${ }^{3}$ (a discussion of nuclear accent follows shortly). One or more APs make up an Intonational Phrase (IP) which usually corresponds to an utterance for monoclausal sentences. ${ }^{4}$ An IP is marked by a low or high right boundary tone (L\% or H\%). Within each IP, everything after the nuclear AP is deaccented, and the AP boundary tone is spread to the right up to the IP end. Deaccenting, a term introduced by Ladd (1980) and widely used in recent years (e.g., Cruttenden 2006, Gussenhoven 2004, Jun 2005, Venditti et al. 1996), here refers to lack of any tonal event or pitch accent. The prosodic structure of Persian is illustrated in Example (4) and Figure 1. An accent mark indicates the stressed syllable, and the nuclear pitch accent (NPA) AP is underlined.

$\begin{array}{llll}\text { (4) lalé } & \text { film-á-ro } & \text { mí-bin-e } & \text { mæmulæn. } \\ \text { Laleh } & \text { movie-PL-RA } & \text { DUR-watch.PRS-3SG } & \text { usually }\end{array}$

'Laleh usually watches the movies.'

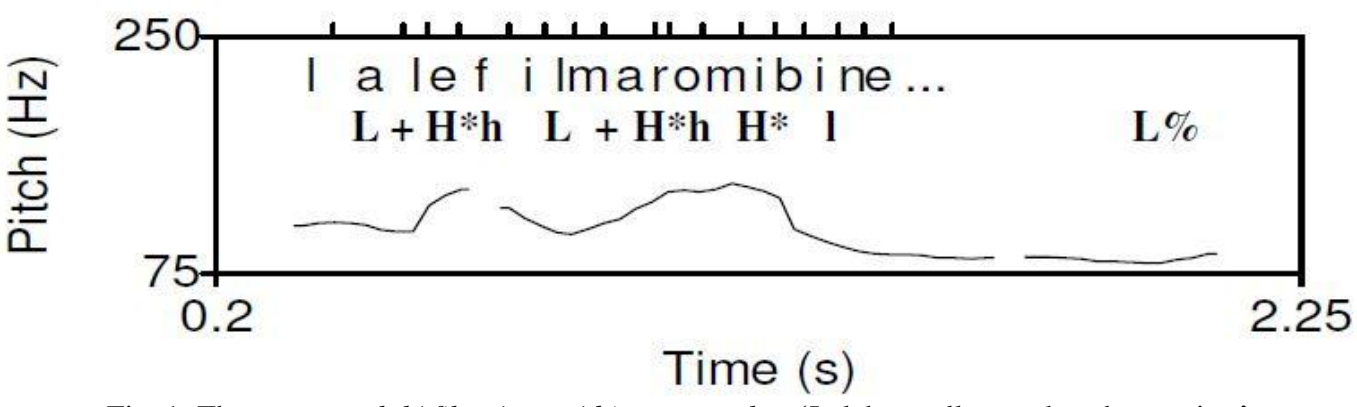

Fig. 1: The utterance lalé film-á-ro mí-bin-e momulan 'Laleh usually watches the movies.'

The utterance in (4) contains three APs. The first two, i.e., the subject Laleh and the direct object film-a 'movies' plus its clitic -ro, have an $\mathrm{L}+\mathrm{H}^{*}$ pitch accent and a high boundary tone, and the third, i.e., the initially stressed verb, carries the $\mathrm{H}^{*}$ pitch accent. This last AP is the NPA of the utterance and has a low boundary tone. The adverb moemulcen 'usually' follows the NPA and is deaccented. The utterance contains one IP, ending with a low IP boundary tone (L\%), which marks it as a declarative.

The intonation pattern of declarative sentences in Persian can be formulized as in (5).

$$
\left((\mathrm{L}+) \mathrm{H}^{*} \mathrm{~h}\right)^{\mathrm{n}} \quad(\mathrm{L}+) \mathrm{H}^{*} 1 \quad \mathrm{~L} \% \quad=0,1,2, \ldots
$$

Parentheses show optionality in the sense that some APs (initially-stressed words and monosyllabic content words) are realized as $\mathrm{H}^{*}$, and power $n$ means that the element under that power can potentially be repeated $n$ times. The simplest case is when the Intonational Phrase

\footnotetext{
${ }^{3}$ Echo questions are exceptions to this generalization since in one version of them the nuclear AP has a high boundary tone (see Subsection 3.6).

${ }^{4}$ A level between AP and IP (i.e., the Intermediate Phrase or ip) has also been suggested for Persian by some scholars but has been left out of this overview, since the simpler two-level system (IP and AP) suffices for the analysis of the present paper.

${ }^{5}$ The enclitic - $r a$ marks an object noun phrase for specificity and is conversationally pronounced as $r o$ (and mostly $o$ after consonants). For different analyses of - ra see, e.g., Dabir-Moghaddam (1992), Ghomeshi (1997b), and Karimi (1996, 2003).
} 
consists of only one AP in which case $n=0$ and the IP is realized as $(\mathrm{L}+) \mathrm{H}^{*} 1 \mathrm{~L} \%$. The number of prenuclear APs can theoretically increase infinitely with $n=1,2, \ldots$

A contrastively-focused element forms its own Accentual Phrase $\left((\mathrm{L})+\mathrm{H}^{*}\right)$ and becomes the NPA. Focused APs are phonetically longer and have a greater pitch excursion than ordinary APs (Sadat-Tehrani 2009). Everything after a focused element is deaccented. Example (6) and its pitch track in Figure 2 are illustrative (contrastive focus is indicated by capitalization) ${ }^{6}$.
lalé $\quad$ FILM-Á-RO mi-bin-e mæmulæn.
Laleh movie-PL-RA
DUR-watch.PRS-3SG usually
'Laleh usually watches THE MOVIES.'

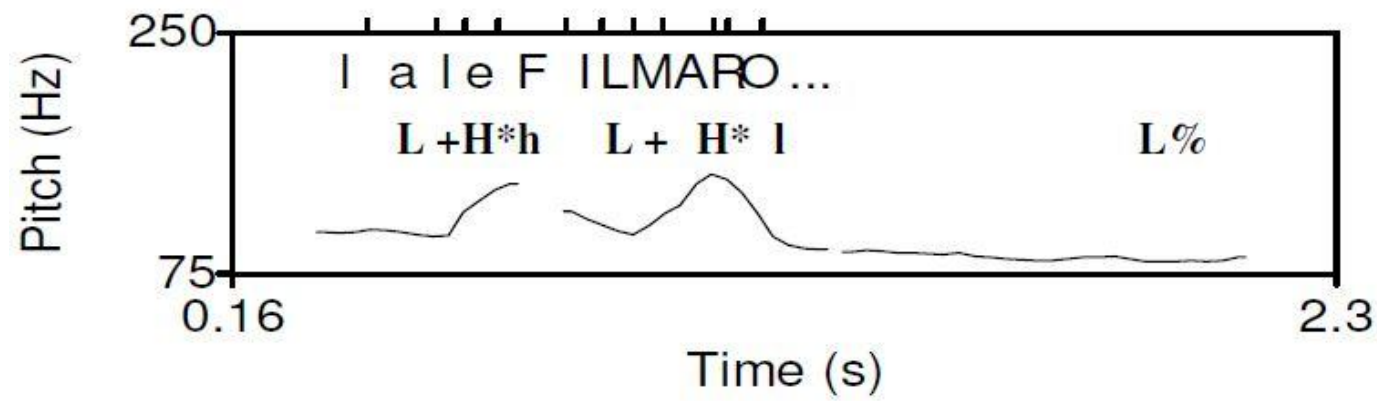

Fig. 2: The contrastive focus utterance lalé FILM-Á-RO mi-bin-e maemulaen 'Laleh usually watches THE MOVIES.'

In (6), which might be used to correct someone who has misheard the direct object film-a-ro 'the movies', the second AP is contrastively-focused and has caused deaccentuation in the following elements.

The concept nuclear pitch accent (NPA), which has also been referred to in the literature with terms such as "nuclear stress" and "sentence stress", can be defined as "the perceptually most prominent accent in a prosodic phrase" (Hirschberg 2002:34), and in the majority of cases in English is the last pitch accent (Cruttenden 1997). For instance, the word station in John ran all the way to the station is nuclear (Cruttenden 1997:75). Persian NPA has been discussed, at least, in the following works: Eslami (2000), Kahnemuyipour (2009), Sadat-Tehrani (2008), and Vahidian-Kamyar (2001). Based on Sadat-Tehrani (2008), the NPA location in Persian monoclausal declaratives obeys the following constraints and rules. In copular verb sentences, the NPA is on the complement, as exemplified in (7). ${ }^{7}$

(7) uná danešjú bud-æn.

they student be.PST-3PL

'They were students.'

Null subject and scrambled sentences follow the same pattern. This is illustrated in (8a) and (8b) respectively.

\footnotetext{
${ }^{6}$ Focus is used in different senses in the literature (see for instance Gussenhoven 2004, Kiss 1998, Ladd 2008, Rizzi 1997, Selkirk 2002, Zubizarreta 1998). Contrastive focus in this paper is taken to mean making one or more elements more prominent in contrast to other elements in the discourse, also referred to as "corrective focus" by Gussenhoven (2007).

${ }^{7}$ The complement is sometimes referred to as the predicate.
} 
(8) a. danešjú bud-æn.

student be.PST-3PL

'[They] were students.'

b. $\frac{\text { danešjú }}{\text { bud-æn }} \begin{aligned} & \text { una. } \\ & \text { be.PST-3PL } \\ & \text { 'They were students.' }\end{aligned}$
they

In cases where the complement is postmodified with the help of the Ezafe vowel, ${ }^{8}$ the modifier bears the NPA. An example is provided in (9).

(9) uná danešjú-ye taríx bud-æn.

they student-EZ history be.PST-3PL

'They were students of history.'

In (9), the NPA is on the complement modifier tarix 'history'.

Unergative SV sentences (i.e., those with agentive subjects) are accented on the verb, as illustrated in (10).
siyavǽš pær-1́d.
Siavash jump-PST.3sG
'Siavash jumped.'

Unaccusative SV sentences (i.e., those with nonvolitional subjects) are accented on the verb if the subject is specific (11a) and on the subject if it is nonspecific (11b).
(11) a. ún namé umád.
that letter arrive.PST.3SG
'That letter arrived.'
b. yé namé umad.
a letter arrive.PST.3SG
'A letter arrived.'

The same specificity constraint holds for the direct object in SOV sentences. In such sentences, the NPA is on the verb if the direct object is specific and on the direct object if it is nonspecific.

The NPA in Persian cannot be on a postverbal element except in adverbial/motion constructions. ${ }^{9}$ An example is provided in (12).

$$
\begin{array}{lll}
\text { miná } & \text { ræft-é } & \underline{\text { xuné. }} \\
\text { Mina } & \text { go.PST-PTCP.3SG } & \text { home }
\end{array}
$$

\footnotetext{
${ }^{8}$ The Ezafe vowel $-e$ (usually pronounced $-y e$ after vowels) syntactically links some elements with their modifiers in Persian. For analyses of the Ezafe construction, see e.g., Ghomeshi 1997a, Larson and Yamakido 2005, Samiian 1994, Samvelian 2007.

${ }^{9}$ These sentences form a rather small subset of Persian sentences and their default word order is non-verb-final. They usually involve movement or contain an adverb of some sort.
} 
'Mina has gone home.'

The NPA in (12) is on xune 'home' which follows the verb.

A negative verb in the sentence attracts the NPA, regardless of any of the above-mentioned factors; however, in the presence of a contrastively-focused element, even the negative verb loses its NPA status. The examples in (13) are illustrative.
I yesterday well NEG-be.PST-1SG
'I wasn't well yesterday.'
a. mǽn dirúz xúb nǽ-bud-æm.
b. mǽn DIRÚZ xub næ-bud-æm.
I yesterday well NEG-be.PST-1SG
'I wasn't well YESTERDAY.'

In (13a), the negative verb (na-bud-am) is nuclear but in (13b), the adverb diruz 'yesterday' is contrastively-focused, i.e., is set against other possible adverbs of time such as today or last week, and has attracted the NPA.

Having seen some characteristics of Persian regarding stress, prosody, and nuclear accent, we deal with the intonation of interrogatives in the next section.

\section{The Intonation of Persian Interrogatives}

This section contains a detailed investigation of the intonation of interrogatives. The study involves ordinary and leading YNQs, YNQs with the question particle aya and those with the adverb hič, tag questions, single and multiple WHQs, and echo questions. Also, the impact of contrastive focus on the intonational structure of YNQs and WHQs is examined.

\subsection{Yes/no questions (YNQs)}

According to Cruttenden (1997), YNQs may be grammatically marked in languages in different ways: by particles, by verb morphology, by word order, and through intonation. In Persian, a declarative and its YNQ counterpart are syntactically identical, and the act of questioning is done by change of intonation (Lazard 1992), a fact which is reported for many languages (e.g., Spanish and Italian (Arvaniti et al. 2006)), and in some languages (e.g., Portuguese, Jacaltec, and Modern Greek) it is the only means of doing so (Cruttenden 1997). In a more formal style, there is the question particle aya (Mahootian 1997), which commonly appears sentence-initially and will be discussed shortly. Let us start with the comparison of a simple SOV sentence and its YNQ counterpart, appearing in (14) and Figures $3 \mathrm{a}$ and $\mathrm{b}$.

(14) a. šagerd-á miz-á-ro avórd-æn.

student-PL table-PL-RA bring.PST-3PL

'The students brought the tables.'

b. šagerd-á miz-á-ro avórd-æn?

student-PL table-PL-RA bring.PST-3PL 
'Did the students bring the tables?'

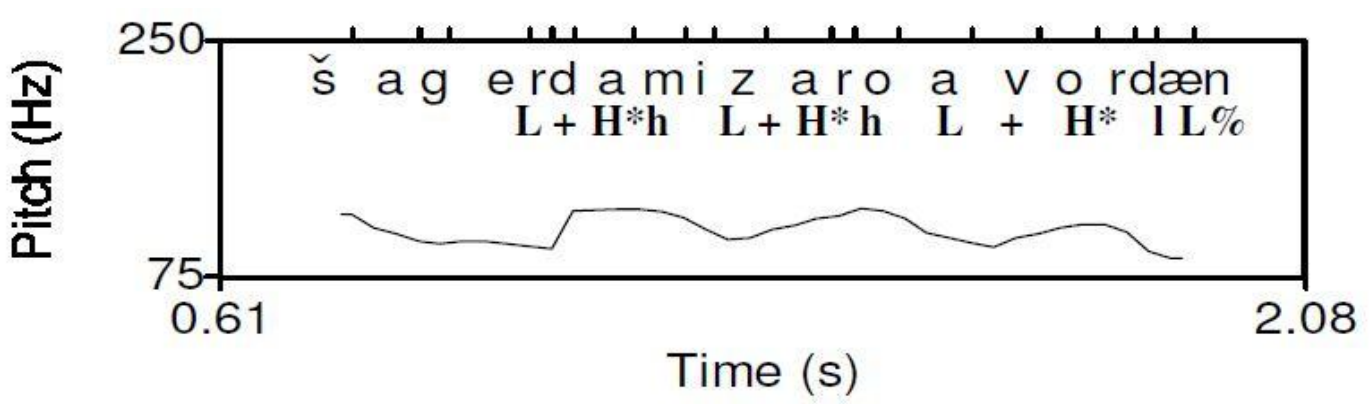

Fig. 3a: The declarative šagerd-á miz-á-ro avórd-ån 'The students brought the tables.'

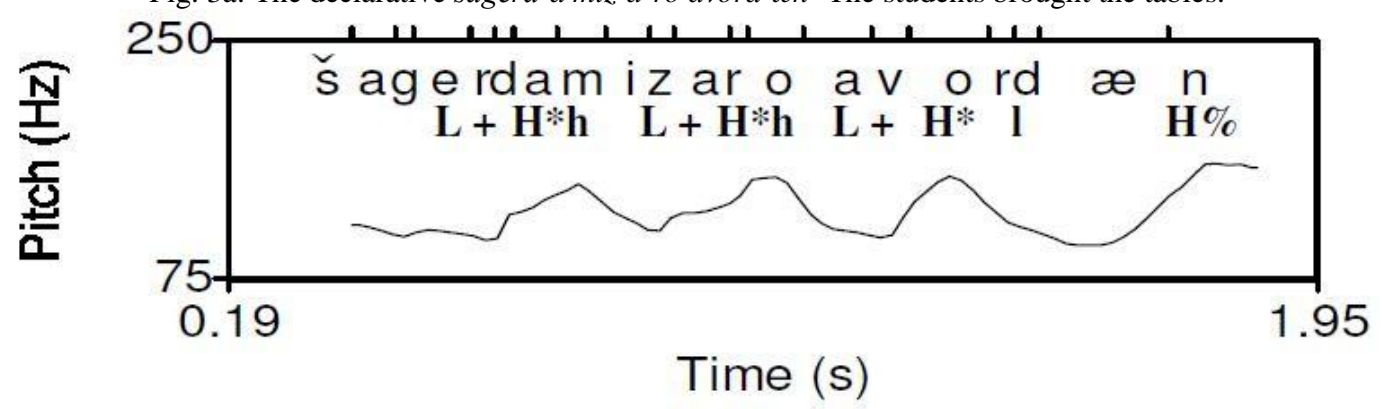

Fig. 3b: The YNQ šagerd-á miz-á-ro avórd-aen 'Did the students bring the tables?'

As can be seen, the tonal pattern of the YNQ is phonologically very similar to that of the declarative: a series of $\mathrm{L}+\mathrm{H}^{*}$ Accentual Phrases with the last AP being the most prominent. In fact, the NPA location of YNQs is always identical to that of declaratives, which makes this language similar to English and different from Russian for instance (Ladd 2008). ${ }^{10}$ The same considerations, e.g., specific/nonspecific or unaccusative/unergative (Section 2), that exist for Persian declaratives are valid for Persian YNQs as well. The difference between the YNQ and the declarative is in the Intonational Phrase boundary tone. While it is low for the declarative (L\%), it is high for the YNQ (H\%). This means a pitch increase on the final syllable of the IP. Thus, we can give the phonological representation of YNQs as in (15).

$$
\left((\mathrm{L}+) \mathrm{H}^{*} \mathrm{~h}\right)^{\mathrm{n}} \quad(\mathrm{L}+) \mathrm{H}^{*} 1 \quad \mathrm{H} \% \quad \mathrm{n}=0,1,2, \ldots
$$

The interpretation of the above formula is the same as that of declaratives (5) in the previous section: $\mathrm{n}=0$ yields the simplest YNQ in the form of $(\mathrm{L}+) \mathrm{H}^{*} \mathrm{H} \%$, and $\mathrm{n}=1,2, \ldots$ create the possibility of one or more prenuclear APs.

Apart from the phonological difference of the IP boundary tone, there are three phonetic differences between declaratives and YNQs. The first is related to the scaling of the $\mathrm{H}^{*}$ which is realized higher in YNQs, hence a greater pitch excursion (H-L). This occurs especially in the final AP due to the fact that there is less declination in YNQs than in declaratives, so the verb AP (avord-an) has a higher peak in the YNQ than in the declarative. This declination contrast is also reported for Danish and Vietnamese (Hirst and Di Cristo 1998) and Estonian (Asu 2002). The second difference concerns the overall pitch register, i.e., the relative position of the pitch contour with regard to the pitch axis. The register for YNQs is higher than that of declaratives,

\footnotetext{
${ }^{10}$ In Russian, the greatest prominence is on the noun following the verb for declaratives, and on the verb for the corresponding YNQ (Ladd 2008).
} 
that is to say that YNQs occupy higher pitches. The third difference between the declarative and its YNQ counterpart is related to final lengthening: Persian YNQs get lengthened at the end, and this can be seen in the increased duration of the vowel /æ/ in the interrogative compared to that of the declarative. This is also observed for Nchufie (Byrd 1992) and for 23 languages of Rialland's (2007) preliminary database of 78 African languages.

The existence of a higher pitch and/or a (final) rise in YNQs is common in other languages as well, for instance, American English, Swedish, Thai, Vietnamese (Hirst and Di Cristo 1998), European Portuguese (Frota 2002b), Mandarin Chinese (Zeng et al. 2004), Samoan (Ortifelli and Yu 2009), to name a few. In Bolinger's (1978) survey, 89\% of his sample of 36 non-tonal languages have a rise or a higher pitch (Cruttenden 1997). There are, however, languages in whose YNQs a final rise is not a common pattern, e.g., Brazilian Portuguese, Bulgarian, Danish, Finnish, Hungarian, Moroccan Arabic, and Russian (Hirst and Di Cristo 1998), Chickasaw (Gussenhoven 2004), and North Kyeongsang Korean (Lee 2008). Grice et al. (1997) report a final rise only in 13\% of their spontaneous tokens of Bari Italian YNQs, and Rialland (2007) states that many of the 78 languages in her African languages database lack a high pitch correlate in their YNQs. ${ }^{11}$

There is one situation in Persian YNQs where the low boundary tone of the final AP is not phonetically realized. This occurs when the stressed syllable of the NPA AP is the final syllable of the IP, illustrated by Example (16) and Figure 4.

$$
\begin{array}{ll}
\text { qænari-yé } & \text { mord-é? } \\
\text { canary-DEF } & \text { die.PST-PTCP.3SG }
\end{array}
$$

Has the canary died?

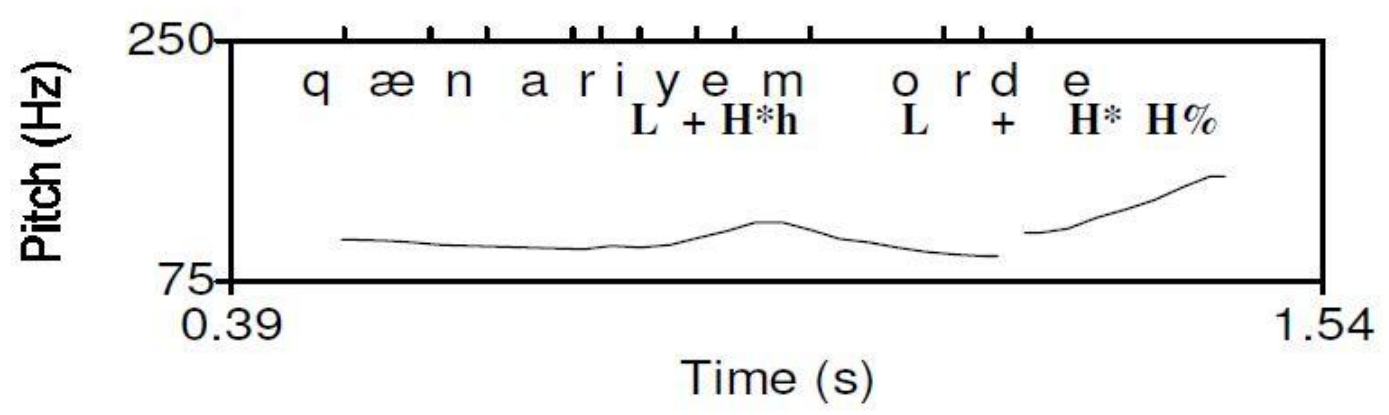

Fig. 4: The YNQ qaenari-yé mord-é 'Has the canary died?'

The stressed participle marker $(-e)$ bears the $\mathrm{H}^{*}$ of the AP's $\mathrm{L}+\mathrm{H}^{*}$. Immediately after this syllable, the IP (and the utterance) rise and go to an end, which leaves no docking site for the AP boundary tone 1 . Consequently, this 1 is deleted.

As mentioned before, formal style YNQs can be formed with the placement of the question particle aya in front of the sentence (and less often in the middle). This type of question is also employed in informal style although to a lesser degree. The use of a particle or enclitic to make a YNQ is not exclusive to Persian and it is employed in other languages as well, e.g., Estonian (Asu 2002), and Latin and Russian (Cruttenden 1997). In Persian YNQs with aya, this initially-

\footnotetext{
${ }^{11}$ Note that information structure may play a role in the intonation pattern of YNQs (see, e.g., Grice and Savino 2003 for Bari Italian and Hedberg et al. 2008 for American English). For instance, in Bari Italian, YNQs may have a rising pitch accent if they ask about new information and a falling one if they ask about given information (Grice and Savino 2003).
} 
stressed particle simply forms a separate Accentual Phrase. Example (17) and its contour in Figure 5 provide an illustration. ${ }^{12}$

áya be dolǽt bæstegi+dašt?

QP to government dependence+have.PST.3SG

'Did it depend on the government?'

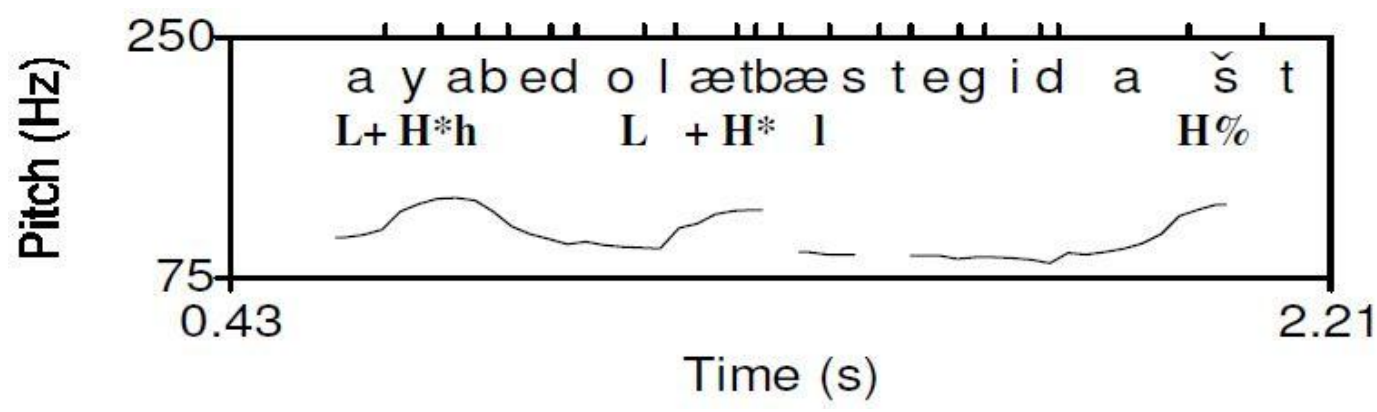

Fig. 5: The YNQ áya be dolćt boestegi+dašt 'Did it depend on the government?' (YNQ with the particle aya).

As observed by Mahjani (2003), YNQs with aya take a slightly lower register than those without this particle. The main reason for this seems to be that with aya part of the act of questioning is done by syntax, and phonology (change of intonation) becomes less crucial. This trade-off is seen in other languages as well, e.g., Beijing Mandarin (Lee 2005) and Estonian (Asu 2002). Also, an utterance with aya is naturally longer than one without, resulting in more declination and more involvement of lower pitches than the non-aya counterpart.

\subsection{Leading YNQs}

The particle mage can appear in the beginning of a YNQ making it a "leading YNQ" (Mahootian 1997). Leading YNQs are also referred to as "biased" questions in the literature (Rezai 2003). This particle can come in other positions in the sentence as well but with less frequency. This type of question involves the speaker's presupposition, in the sense that she assumes the opposite polarity answer. So in positive leading YNQs a negative answer is assumed and vice versa. Prieto and Rigau (2007) refer to this question type as "antiexpectational". In this sense, the function of such interrogatives is similar to that of tag questions. An example of a leading YNQ is provided in (18).

(18) mæge æli unja næ-bud?

PTC Ali there NEG-be.PST.3SG

'Wasn't Ali there then?'

The word 'then' in the gloss shows the presupposition involved in the Persian question. An alternative translation for (18) would be 'Ali was there, wasn't he?' where the speaker assumes a positive answer.

Intonationally, there are two alternatives for the particle mage. It can either form an independent AP or become part of the next AP. Whatever follows mage usually has the basic pattern of a declarative although with a slightly higher pitch register. This higher register seems

\footnotetext{
${ }^{12}$ Note that although the particle aya is initially-stressed, it is represented as $\mathrm{L}+\mathrm{H}^{*}$ due to an utterance initial rise.
} 
to carry the load of expectation (and surprise) inherent in this question type. Figures 6a and $\mathrm{b}$ contain the pitch tracks of two interchangeable productions of (18)

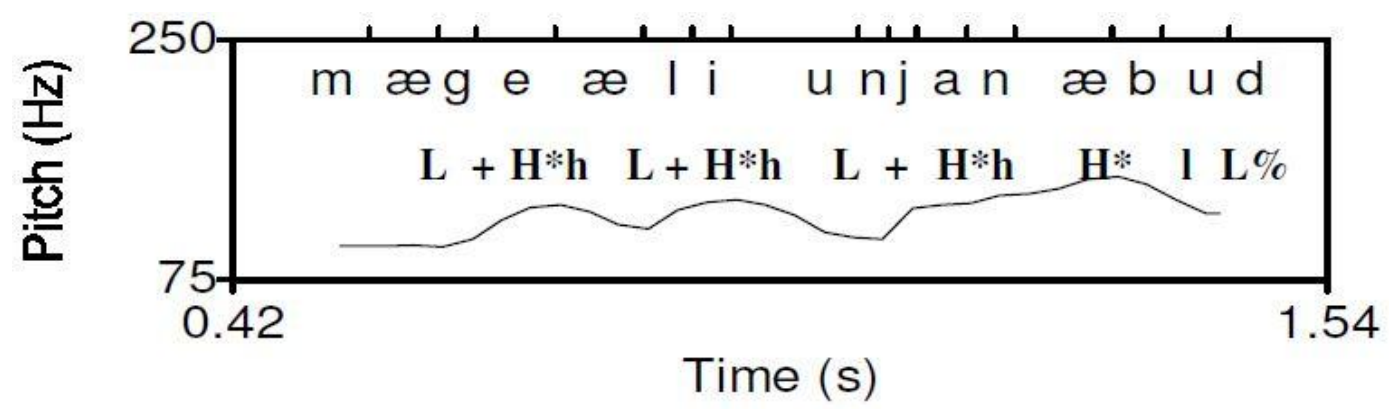

Fig. 6a: The leading YNQ magé ali unjá nóe-bud 'Wasn't Ali there then?'

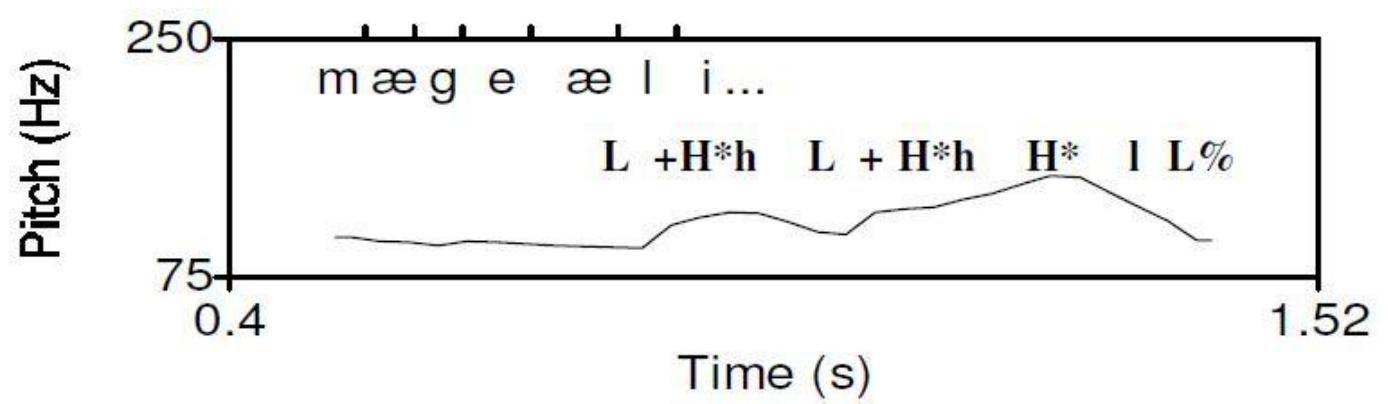

Fig. 6b: The leading YNQ mage celi unjá nóe-bud 'Wasn't Ali there then?' (alternative pronunciation).

Figure 6a shows mage as a separate AP while in Figure 6b, both syllables of this particle are realized low and form part of the L of the next AP ali 'Ali'. In both pronunciations, the part after mage, i.e., ali unja na-bud, behaves like an ordinary declarative with the phonological representation of $\mathrm{L}+\mathrm{H}^{*} \mathrm{~h} \mathrm{~L}+\mathrm{H}^{*} \mathrm{~h} \mathrm{H}^{*} 1 \mathrm{~L} \%$.

Another less common, but equally grammatical, intonation for what follows mage is that of an ordinary YNQ with an H\% at the IP end. This option adds to the degree of surprise in the utterance. The tonal patterns of (18) with this option are provided in (19). Again, there are two possibilities for mage, as a separate AP (19a) and as part of the next AP (19b).
mæge
æli
unja
$\underline{\text { næ-bud? }}$

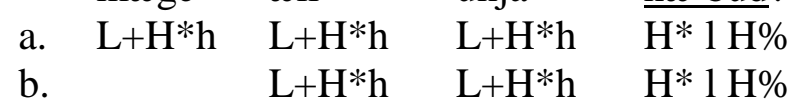

The particle mage can also cooccur with WHQs which produce a stronger attitude of surprise than in YNQs. Such interrogatives will be discussed in Subsection 3.4.

Before closing the subsection on YNQs, let us briefly discuss another word which appears in YNQs, the word hič with the literal meaning 'nothing' (Bateni 1969, Khanlari 2001, Sadeghi and Arjang 1986). This word in fact functions like an adverb in YNQs and is the equivalent of 'at all'. Example (20) is illustrative.
híč
tæqír-i-æm
kærd-é-bud?
nothing change-IND-CL
do.PST-PTCP-be.PST.3SG

'Had it changed at all?' 
hic is usually one AP with the pattern $\mathrm{H}^{*}$ or $\mathrm{L}+\mathrm{H}^{*}$ (the latter when it occurs sentence initially) and it does not affect the basic intonation of the YNQ it occurs in. Figure 7 which contains the pitch track of Example (20) demonstrates this fact.

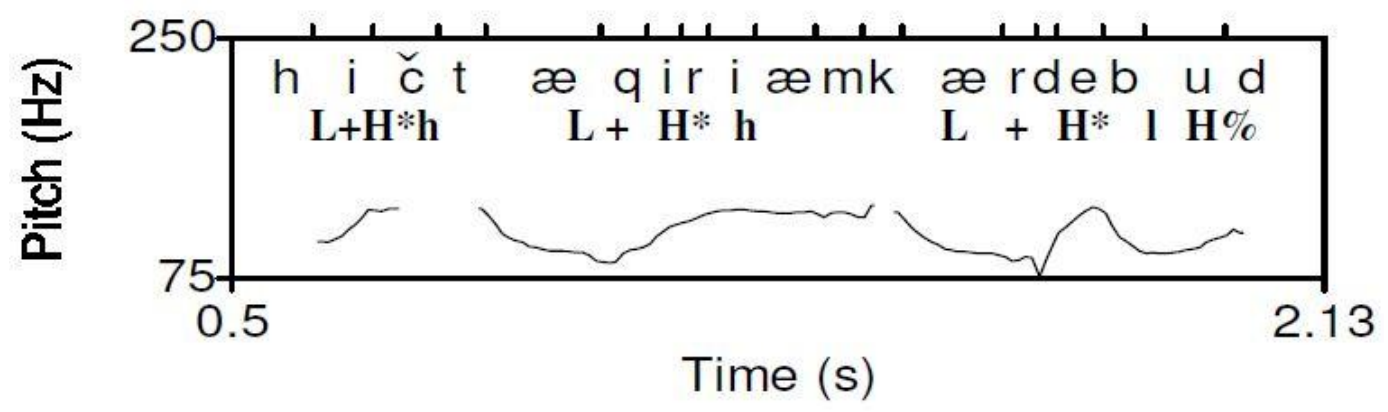

Fig. 7: The YNQ hič taqír-i-aem kard-é-bud 'Had it changed at all?'

taeqir-i-aem+kard-e-bud? is a neutral YNQ with its typical pattern discussed above. The adverb hic has only added another AP in the form of $\mathrm{L}+\mathrm{H}^{*}$ with a high AP boundary tone, which is not the NPA of the utterance.

\subsection{Tag questions}

The most common tag in Persian is in the form of the single word na 'no', as exemplified by (21).
ba mǽn mí-ay-n, nǽ?
with I DUR-come.PRS-2PL no
'You're coming with me, aren't you?'

The word are 'yeah' can replace na, though its usage is more limited. Tags can also be verbal which consist of a verb with a polarity opposite to that of the pretag. For example, the above sentence can be used with the negative of the verb mi-ay- $n$ in the tag, as given in (22).

$$
\begin{aligned}
& \text { ba mǽn mí-ay-n, } \quad \text { né-mi-ay-n? } \\
& \text { with I } \quad \text { DUR-come.PRS-2PL } \\
& \text { 'You're coming with me, aren't you?' }
\end{aligned}
$$

Figures $8 \mathrm{a}$ and $\mathrm{b}$ contain the pitch tracks of the utterances in (21) and (22).

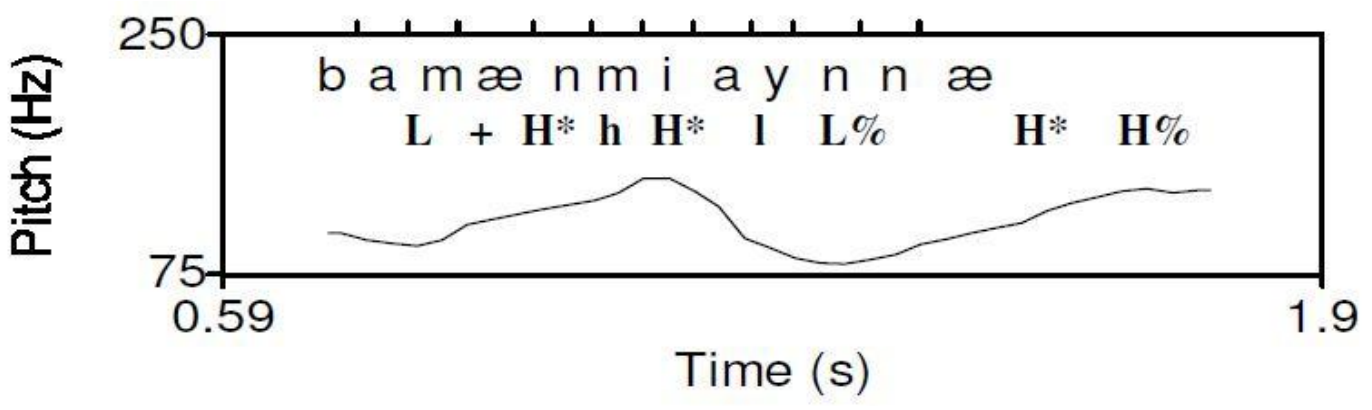


Fig. 8a: The utterance ba món mi-ay-n, nó 'You're coming with me, aren’t you?' (tag question).

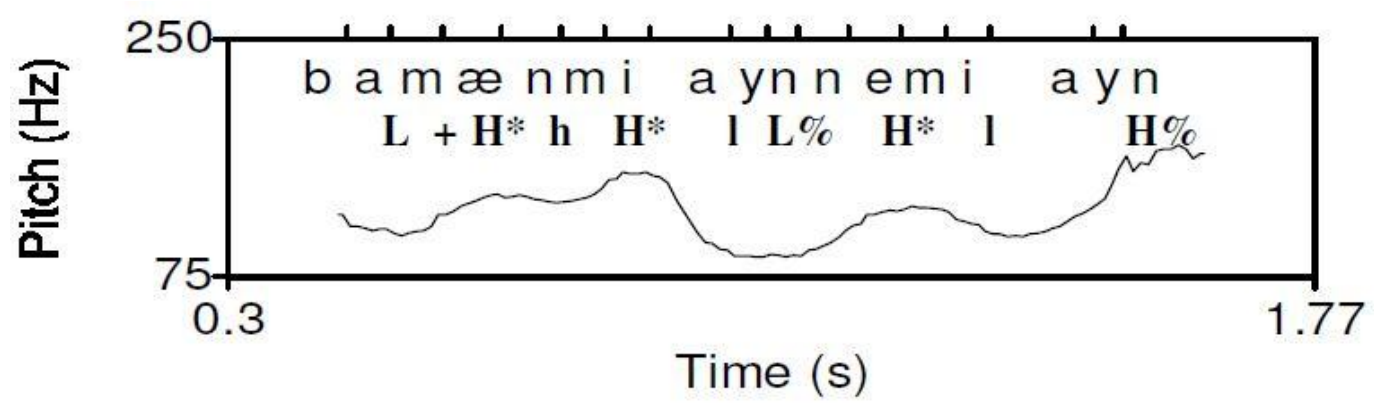

Fig. 8b: The utterance ba món mi-ay-n, né-mi-ay-n 'You're coming with me, aren’t you?' (tag question).

Tags are intonationally realized as a separate Intonational Phrase. There are two reasons for this claim. First, each part of the sentence, i.e., pretag and tag, has a nuclear pitch accent of its own. For instance, in 8b above, the verbs bear the NPA: $m i-a y-n$ for the pre-tag and $n e-m i-a y-n$ for the tag. If the tag and the pretag were in the same IP, there would only be one NPA in the whole IP and this is impossible: the NPA cannot be only on the pretag verb $(m i-a y-n)$ since it would cause deaccentuation in the tag verb (ne-mi-ay-n) which is not the case; and the NPA cannot be only on the tag verb since the pretag verb would have to be prenuclear which is also not the case (since it is low-boundary-toned). Second, there is usually a small pause between the pretag and the tag (more for verbal tags than for nonverbal tags), which is one of the diagnostics for the existence of an IP break. This observation is supported by the use of a comma in writing before the tag. So, the tag is in a separate IP with a separate NPA and the whole tag construction is an utterance consisting of two IPs.

With the above consideration, the intonational analysis of tag questions follows easily. The whole tag construction is a linear combination of two independent structures: a pretag which behaves like an ordinary declarative, and a tag which behaves like an ordinary YNQ. In the above figures, the pretag ba mon mi-ay- $n$ has the intonation of a normal declarative and the tag $n a$ (Figure 8a) or $n e-m i-a y-n$ (Figure $8 \mathrm{~b}$ ) is added to it as a separate IP having the pattern of a YNQ. Note that in the noe version, the low AP boundary tone of the tag is not realized because the AP ends in a stressed syllable (see Subsection 3.1). The diagram in (23) summarizes the foregoing analysis.

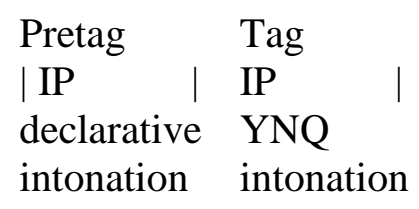

Tags have been reported to behave in a similar fashion in other languages. They form a separate intonation unit with a YNQ intonation pattern in English, French, Romanian, European Portuguese, and Moroccan Arabic (Hirst and Di Cristo 1998), and they are characterized by a high final boundary tone in Paiwan (Chen 2010). ${ }^{13}$

\footnotetext{
${ }^{13}$ Here, there should be a mention of English tags which show a dual behavior: they can be either falling or rising, depending on the intended pragmatic meaning. For instance, the former can be confirmation-seeking and the latter information seeking (e.g., Tottie and Hoffmann 2006).
} 
To sum up the intonation of Persian YNQs, these sentences have the basic pattern of a series of $\mathrm{L}+\mathrm{H}^{*}$ Accentual Phrases identical to declaratives but their Intonational Phrase boundary tone is $\mathrm{H} \%$ and not $\mathrm{L} \%$ as in declaratives. The location of the nuclear pitch accent is identical to that in declaratives and all the restrictions stated in Section 2 for declaratives (e.g., specific/nonspecific or unaccusative/unergative contrasts) are valid for YNQs as well. YNQs exhibit more pitch excursion on the nuclear pitch accent Accentual Phrase, an overall higher pitch register, and more final lengthening than declaratives. The particle aya can be added to a YNQ in a more formal style, which is realized as an additional AP and does not influence the intonational phonology of the rest of the sentence. Leading (mage) YNQs mostly end with a falling intonation like declaratives and the particle mage is realized either as a separate AP or as part of the L of the following AP. The adverb hic 'nothing' can be added to a YNQ for emphasis and is assigned one AP. Tag questions are composed of two IPs, the first behaving like a simple declarative and the second like a YNQ.

The next subsection deals with questions having a WH-word, i.e., WH-questions.

\subsection{WH-questions (WHQs)}

WH-words in Persian, which include $k i$ 'who', či 'what', key 'when', čera 'why', koja 'where', and kodum 'which', remain in situ in their unmarked order. Consider the unmarked declarative in (24).

$$
\begin{aligned}
& \text { bæčče-ha æz un mæqaze ketab xær-id-æn. } \\
& \text { child-PL from that shop book buy-PST-3PL } \\
& \text { 'The children bought books from that shop.' }
\end{aligned}
$$

In this sentence, which has the order $\mathrm{S} P \mathrm{PP} \mathrm{V}^{14}$, every element can be questioned about using a WH-word. Three of the possible WHQs for (24) are given in (25).
a. $\mathrm{ki}$
$æ$ un
mæqaze ketab
book
who from that shop
'Who bought books from that shop?'
b. bæčče-ha æz koja ketab xær-id-æn? child-PL from where book buy-PST-3PL 'Where did the children buy books from?'
c. bæčče-ha æz un mæqaze či xær-id-æn? child-PL from that shop what buy-PST-3PL 'What did the children buy from that shop?'

xær-id?

As can be seen in the above examples, Persian WH-words $k i$ 'who', koja 'where', and či 'what' are in their normal position. Such words can also be topicalized (Raghibdust 1994) or moved due to scrambling (Karimi 2003, 2005). The sentence in (26) exemplifies the topicalization of $c i$.

\footnotetext{
${ }^{14}$ Note that a non-specific object is adjacent to the verb in its most neutral surface position (Karimi 2005), so $\mathrm{S}$ PP O V can be considered the canonical order of (24).
} 


$$
\text { či bæčče-ha æz un mæqaze xær-id-æn? }
$$

what child-PL from that shop buy-PST-3PL

'What was it the children bought from that shop?'

The Persian WH-word is usually the most prominent word in the sentence as far as information structure is concerned. This is encoded in Persian in the location of the nuclear pitch accent: it is always on the WH-word. This prominence property, which is different from the pattern in English, is shared by some other languages such as Turkish and Bengali (Ladd 2008). Let us examine the pitch contour of Example (25b) in Figure 9.

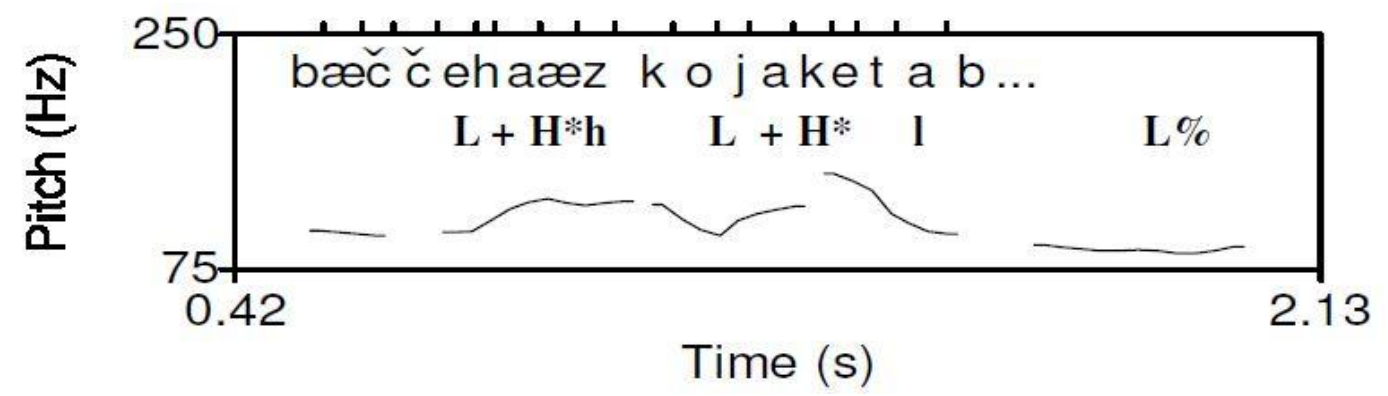

Fig. 9: The WHQ bačče-há azz kojá ketab xar-id-aen 'Where did the children buy books from?'

An AP has been assigned to the WH-word koja 'where'. The subject noun phrase boečce-ha 'children' takes one AP too (note that the preposition $a z$ ' 'from' which is usually low is realized high due to fast speech rate and is merged with the previous AP bcečce-ha). Everything following the WH-word, i.e., ketab xar-id-aen, is deaccented. Similar to default declaratives, the IP and the utterance end low, marked with an L\%. The similarity of the intonation patterns of WHQs and declaratives has been observed cross-linguistically too, and in fact, fall is the dominant pattern for WHQs in languages (Cruttenden 1997). American English (Hedberg et al. 2010), European Portuguese (Frota 2002b), Greek, Romanian, and Russian (Hirst and Di Cristo 1998), Paiwan (Chen 2010), Spanish and Standard Italian (Sosa 1999 and Avesani 1995, quoted in Frota 2002b) can be named as individual examples. However, differences between the two contours have been reported as well, for instance, a steeper downtrend or average F0 slope in WHQs is observed for Dutch (Van Heuven and Haan 2000) and British English (Grabe et al. 2005).

There is often a pitch increase on the $\mathrm{H}$ of the Persian WH-word AP, a phenomenon that stems from the focus nature of WH-words, seen also in Dutch (Haan 2002), Mandarin (Lee 2005, $\mathrm{Hu}$ 2002), Romanian and Russian (Hirst and Di Cristo 1998), and Tamil (Keane 2006). Yet Persian WH-words can be realized still higher if they are contrastively-focused themselves (see Subsection 3.8).

Monosyllabic WH-words, e.g., $k i$ 'who', and initially-stressed ones, e.g., čera 'why' are realized as $\mathrm{H}^{*}$.

Due to the focus nature of WH-words, they cannot normally occur postverbally, as illustrated by the ungrammaticality of (27). ${ }^{15}$

$\begin{array}{lllll}\text { *bæčče-ha } & \text { ketab } & \text { xær-id-æn } & \text { æz } & \text { koja? } \\ \text { child-PL } & \text { book } & \text { buy-PST-3PL } & \text { from } & \text { where }\end{array}$

\footnotetext{
${ }^{15}$ This sentence can be grammatical in a contrastive focus context (e.g., ketab 'book' as opposed to daefter 'notebook' where ketab deaccents everything after it), which is irrelevant for the discussion at hand.
} 
Intended to mean: 'Where did the children buy books from?'

This is owing to the fact that the verb xaer-id-aen triggers deaccentuation after it and does not allow the question word koja to form an AP, so this word must come before the verb. However, in adverbial/motion constructions (Section 2) it is possible for the WH-word to appear after the verb. Recall that these constructions are not verb-final in default order. Example (28) is repeated from (12).

$$
\begin{array}{ll}
\text { miná ræft-é } & \underline{\text { xuné. }} \\
\text { Mina go.PST-PTCP.3SG } & \text { home } \\
\text { 'Mina has gone home.' } &
\end{array}
$$

The word xune 'home' is not deaccented and bears the NPA of the utterance. If a WHQ is asked about this word, the WH-word will normally appear after the verb and accented. Example (29) and Figure 10 are illustrative.
miná ræft-é kojá?
Mina go.PST-PTCP.3SG where
'Where has Mina gone?'

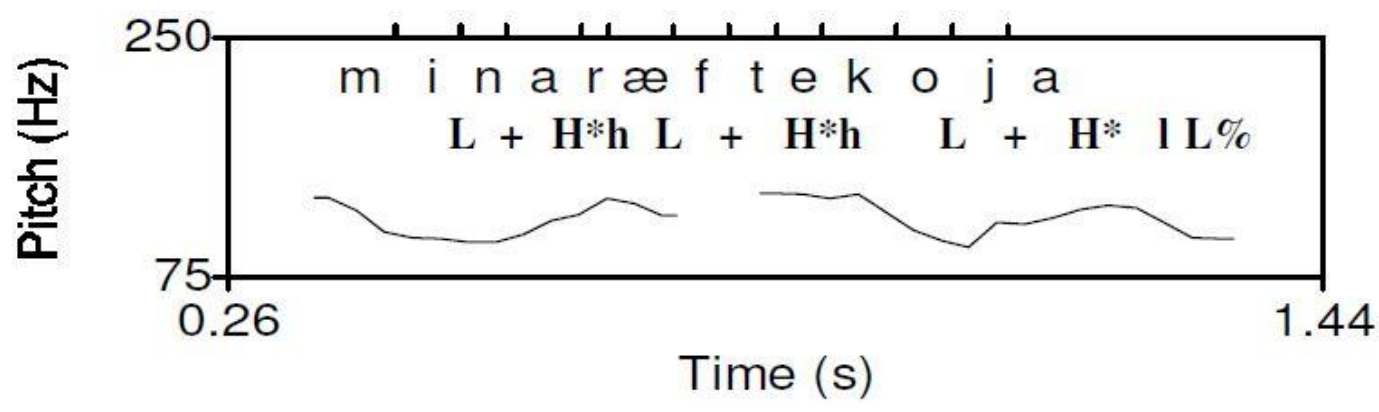

Fig. 10: The utterance miná raeft-é kojá 'Where has Mina gone?' (WHQ in adverbial/motion construction).

The WH-word koja has occurred postverbally but retained its AP structure and nuclear accent since it is in an adverbial/motion construction.

The particle mage, studied in Subsection 3.2 under leading YNQs, can also occur in most WHQs. Here, this particle connotes more surprise than expectation. An example is provided in (30) and Figure 11.

$$
\begin{array}{lll}
\text { mæge } & \text { kéy } & \text { umæd-i? } \\
\text { PTC } & \text { when } & \text { come.PST-2SG }
\end{array}
$$

'When did you come then?' [With surprise] 


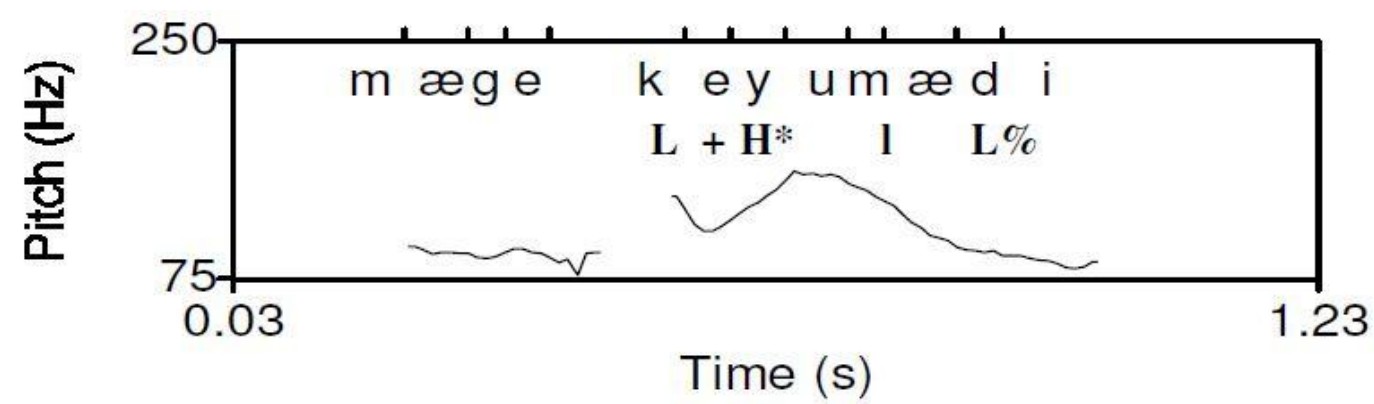

Fig. 11: The utterance mage kéy umaed-i 'When did you come then?' (WHQ with the particle mage).

As in leading YNQs, mage can form a separate AP or be (part of) the L of the next AP, without affecting the NPA (in the above figure it is part of the next AP). Similar to any simple WHQ, the NPA is on the question word key 'when' after which the verb (umad-i) is deaccented.

To summarize the intonational behaviour of WHQs so far, these sentences are comprised of a series of Accentual Phrases with the pitch accent $\mathrm{L}+\mathrm{H}^{*}$. The question word forms a separate AP which often bears the nuclear pitch accent of the utterance and its following elements are deaccented. There is usually a pitch increase on the AP peak in the WH-word. The Intonational Phrase ends in the lower part of the speaker's range, hence marked with an L\%.

We now move on to questions that contain multiple WH-words.

\subsection{Multiple WH-word questions}

WHQs in Persian can contain more than one WH-word. As in the case of single WH-word questions, the WH-words in a multiple WH-word question can remain in situ or be topicalized. Consider Example (31) repeated from (24).
bæčče-ha æz un mæqaze ketab xær-id-æn. child-PL from that shop book buy-PST-3PL

'The children bought books from that shop.'

Example (32) contains two of the possible two-WH-word questions related to (31). The question words are italicized.
a. bæčče-há æz kojá či xær-id-æn?
child-PL from where what buy-PST-3PL
'What did the children buy from where?'
b. æz kojá bæčče-há či xær-id-æn?
from where child-PL what buy-PST-3PL
'What did the children buy from where?'

Example (32a) has the question words koja 'where' and či 'what' in situ, while in (32b) koja has been topicalized. Note that here we are not dealing with focused elements, so a pair-listing interpretation is intended for both sentences. The relevant context can be that the children wanted to buy different things from different places and the questioner is asking what they bought and from where. 
Now, consider the pitch tracks of the sentences in (32), which are given in Figures 12a and b.

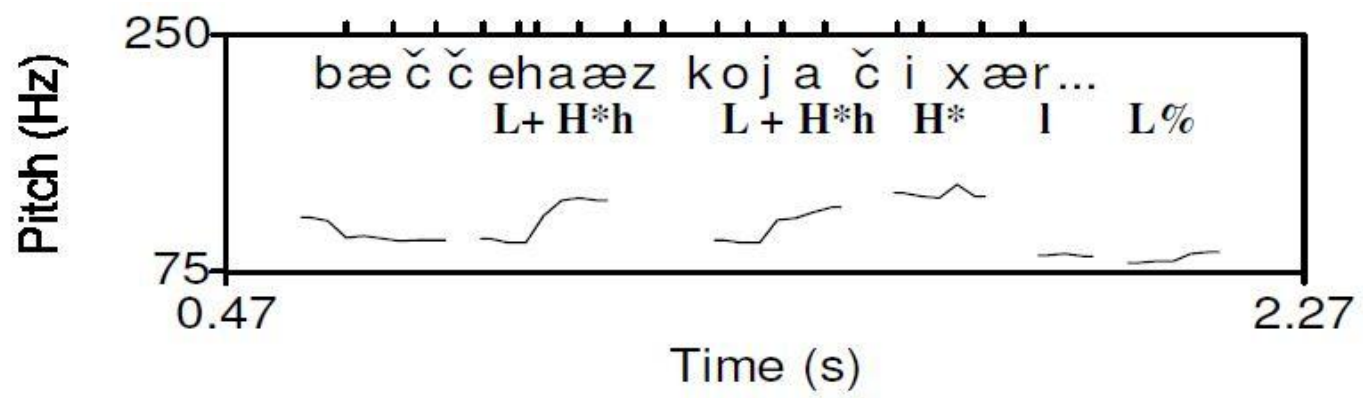

Fig. 12a: The two-WH-word question bæečče-há cez kojá čí xcer-id-an 'What did the children buy from where?' (in situ).

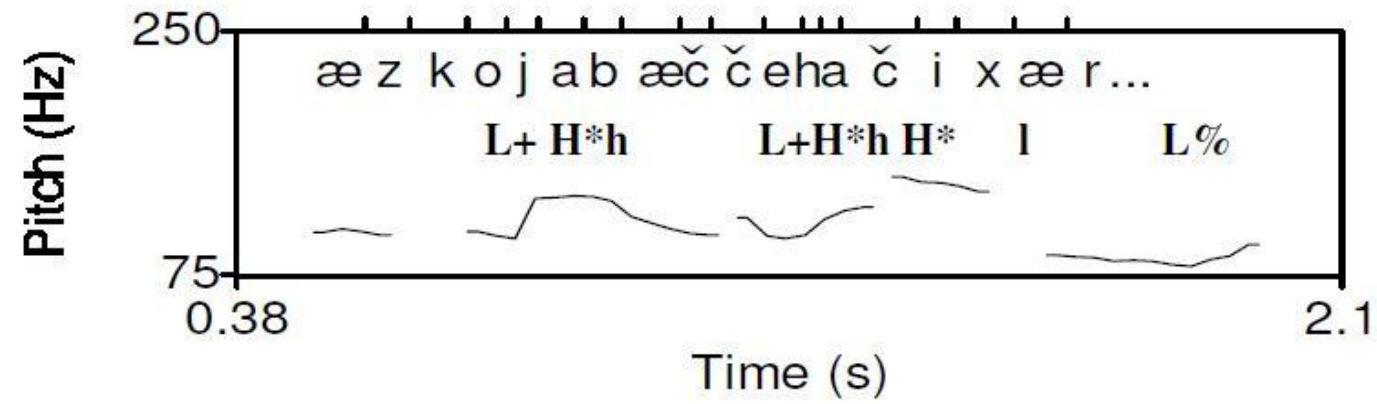

Fig. 12b: The two-WH-word question cez kojá bačče-há či xaer-id-æen 'What did the children buy from where?' (topicalized).

The intonational analysis is rather straightforward. Two-WH-word questions have a series of Accentual Phrases, the last of which is assigned to the second WH-word. This AP is the NPA of the utterance and naturally deaccents everything after it. The first WH-word acts like an ordinary $\mathrm{AP}$ and does not trigger deaccentuation. So in Figures 50a and 50b, cez koja 'from where' is an ordinary AP marked with an $\mathrm{L}+\mathrm{H}^{*}$ pitch accent and an h boundary tone. $c i$ 'what' being the second $\mathrm{WH}$-word forms the last AP (realized as $\mathrm{H}^{*}$ ) with a low boundary tone and carrying the nuclear stress. Note that in Figure 50b, there is one non-WH-word AP (bcečce-ha) between the two WH-word APs which retains its AP status and is not deaccented after az koja.

There is no fundamental change when the utterance contains more than two WH-words, as illustrated in (33) and Figure 13.

dirúz ki kodúm mehmun-o kojá
yesterday who which guest-RA where
'Who took which guest where yesterday?'

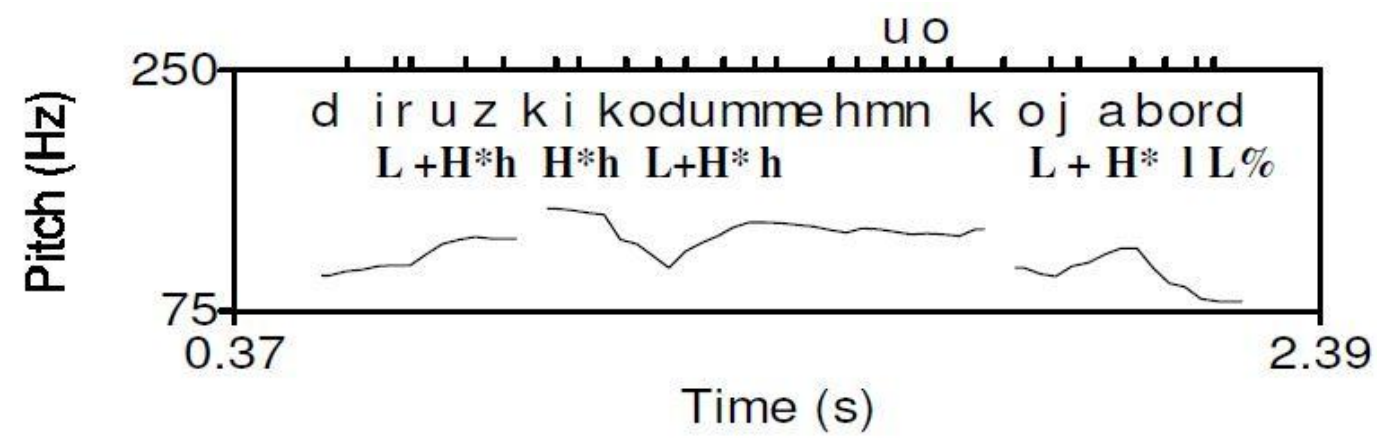


Fig. 13: The three-WH-word question dirúz kí kodúm mehmun-o kojá bord 'Who took which guest where yesterday?'

There are four APs in (33), the adverb diruz, the WH-word ki, the WH-determiner and its head kodum mehmun-o, and the WH-word koja, with the fourth being the NPA and having a low AP boundary tone. The Intonational Phrase boundary is L\% as before. The second AP ( $k i)$ is realized as $\mathrm{H}^{*}$ since it is monosyllabic. The head of the WH-determiner, i.e., mehmun-o, bears the high AP boundary tone.

Having investigated the behaviour of WHQs with one or more question words, in the next subsection we turn to echo questions.

\subsection{Echo questions}

An echo question usually repeats all or part of what has just been uttered and asks for clarification or expresses surprise. Such interrogatives are also referred to as repeat questions (Hirst and Di Cristo 1998). An echo question is either in the form of a YNQ or a WHQ, and is segmentally identical to the neutral version of that question. An example of an echo YNQ is given in (34). This sentence can be uttered in response to an utterance like 'Sayeh bought me a car'.

$$
\begin{aligned}
& \text { sayé bærá-t mašín xær-id? } \\
& \text { Sayeh for-you car buy-PST.3SG } \\
& \text { 'Sayeh bought you a car?' [Echo question] }
\end{aligned}
$$

The intonation of echo YNQs is identical to that of contrastive focus constructions. The echo question above for instance has the same intonation as when the utterance is a nonecho question but the word mašin 'car' is contrastively-focused. ${ }^{16}$ For this reason, this type of echo question will be dealt with in Subsection 3.7, and here we only study echo WHQs.

There are no structural constraints on echo WHQs and any WHQ can be used as an echo question. Let us look at Example (35).

$$
\begin{array}{lllll}
\text { arezú } & \text { čí-ro } & \text { ru miz } & \text { gozašt? } \\
\text { Arezu } & \text { what-RA on table put.PST.3SG } \\
\text { 'Arezu put what on the table?' [Echo question] }
\end{array}
$$

A speaker may ask this question if she hasn't heard the object that Arezu put on the table in the previous discourse. There are two alternative intonations for (35). They are provided in Figures $14 \mathrm{a}$ and $\mathrm{b}$.

\footnotetext{
${ }^{16}$ Example (34) also has another (less frequent) pronunciation (see footnote 19).
} 


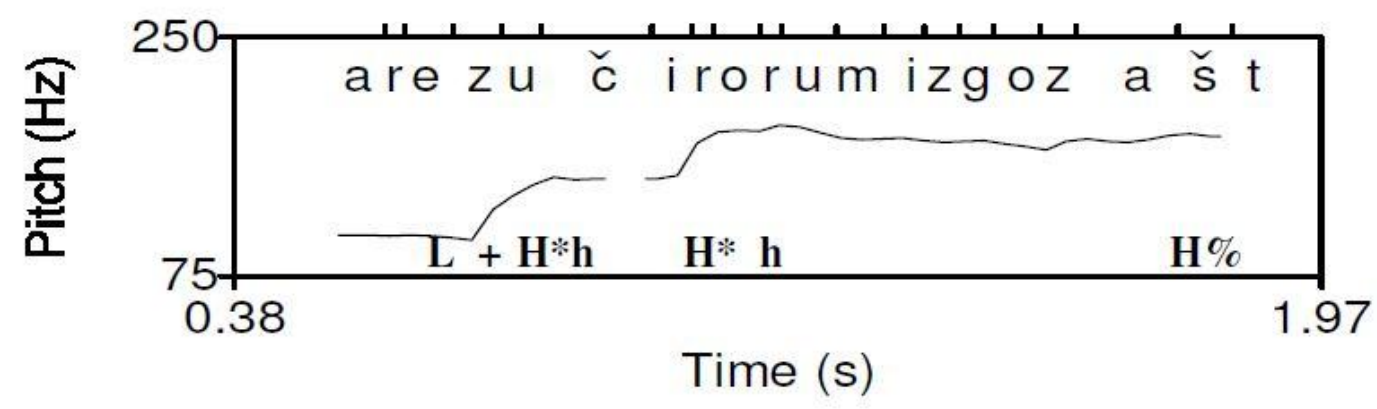

Fig. 14a: The echo WHQ arezú či-ro ru miz gozašt 'Arezu put what on the table?' (first alternative).

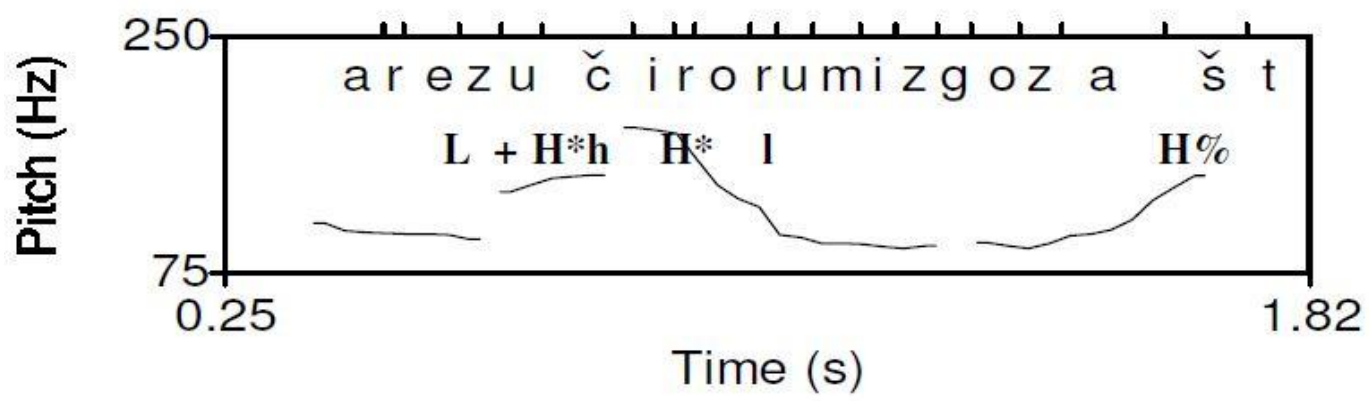

Fig. 14b: The echo WHQ arezú čí-ro ru miz gozašt 'Arezu put what on the table?' (second alternative).

Both alternatives have two APs, the first of which (the name arezu with the pattern $\mathrm{L}+\mathrm{H}^{*} \mathrm{~h}$ ) is identical in the two. Also, the Intonational Phrase boundary tone for both alternatives is $\mathrm{H} \%$, a characteristic shared by many languages, e.g., American English (Hedberg et al. 2010) and Finnish, French, Portuguese, Romanian, and Swedish (Hirst and Di Cristo 1998) and. The difference between the two alternatives lies in the boundary tone of the second AP či-ro. It is high for the first version and low for the second. This boundary tone, as mentioned in Section 2, spreads to the end of the IP. Note that unlike other monoclausal Persian sentences, the boundary tone of the NPA AP in the first alternative is high.

There is an intriguing characteristic to note about the second alternative: it has an intonation pattern identical to that of YNQs. This point is illustrated with Example (36) and Figure 15.

$\begin{array}{lllll}\text { arezú } & \text { ŠÍR-O } & \text { ru } & \text { miz } & \text { gozašt? } \\ \text { Arezu } & \text { milk-RA } & \text { on } & \text { table } & \text { put.PST.3SG }\end{array}$

'Did Arezu put THE MILK on the table?'

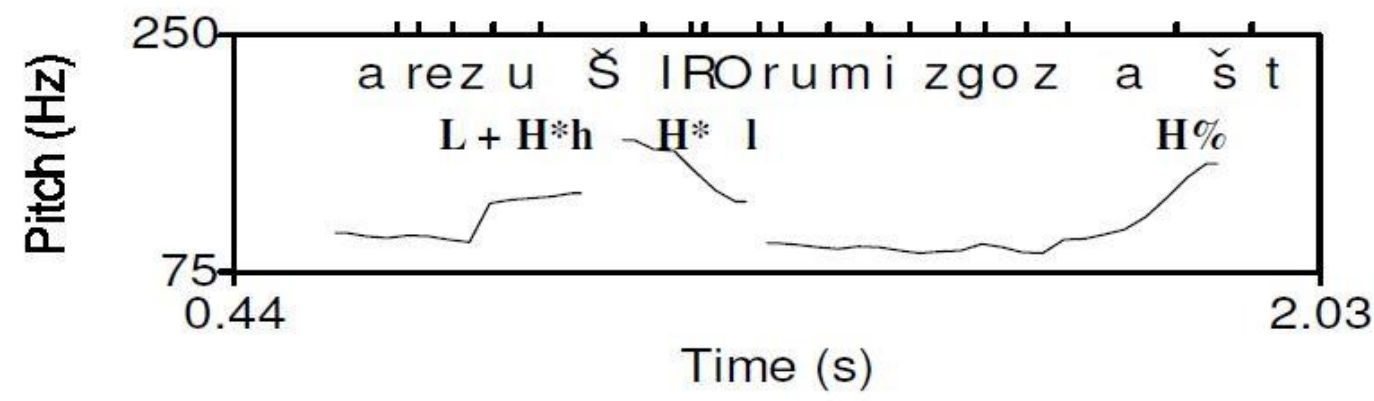

Fig. 15: The YNQ arezú ŠÍR-O ru miz gozašt ‘Did Arezu put THE MILK on the table?' 
Examples (36) and (35), a YNQ (in this example with a focused direct object) and an echo WHQ respectively, which are segmentally almost equal, share the same intonation contour. This characteristic makes the second version of WH-echo questions susceptible to the same constraint that existed for YNQs: if the utterance ends with a stressed syllable, the (final) low AP boundary tone is not realized. As a result, echo WHQs ending with a stressed syllable can only have one alternative, namely the one with a high AP boundary tone for the final AP. An example of such echo WHQs is given in (37) and Figure 16.

kojá?

where

'Where?' [Echo question]

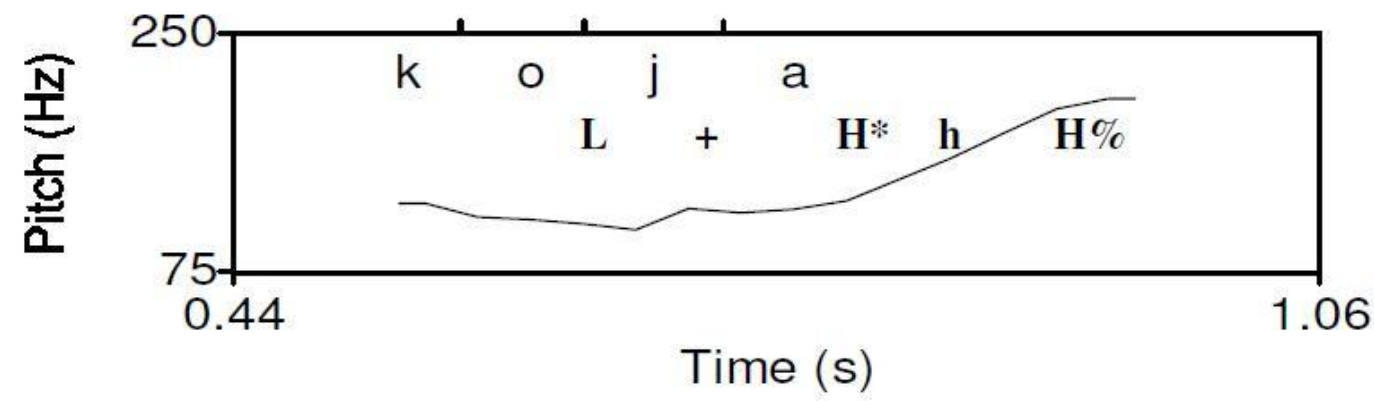

Fig. 16: The echo WHQ kojá 'Where?'

As can be seen, there is no room between the $\mathrm{H}^{*}$ and the $\mathrm{H} \%$ for a low AP boundary tone to realize and consequently the high AP boundary tone takes over. Thus, the second syllable of koja is associated with $\mathrm{H}^{*}, \mathrm{~h}$, and $\mathrm{H} \%$. In such a situation, the difference between the two alternative intonations of echo WHQs is neutralized in favour of the version with a high AP boundary tone.

In sum, echo WHQs can have one of the representations in (38).
a. $\left((\mathrm{L}+) \mathrm{H}^{*} \mathrm{~h}\right)^{\mathrm{n}} \quad \mathrm{H} \%$
b. $\left((\mathrm{L}+) \mathrm{H}^{*} \mathrm{~h}\right)^{\mathrm{n}}$
$(\mathrm{L}+) \mathrm{H}^{*} 1 \mathrm{H} \%$
$\mathrm{n}=1,2,3, \ldots$
$\mathrm{n}=0,1,2, \ldots$

In (38a), all the Accentual Phrases, including the nuclear one, have a high boundary tone. In (38b), the final AP has a low boundary tone. Echo WHQs whose final syllable is stressed cannot have the option in (38b) since there is no docking site in them for the 1.

The next two subsections look at the effect of contrastive focus on Persian interrogatives.

\subsection{Contrastive focus in YNQs}

As seen in the declarative of Example (6) and Figure 2 in the introduction (repeated below as (39) and Figure 17), a contrastively-focused element forms its own Accentual Phrase with a low boundary tone and causes deaccentuation up to the IP end.

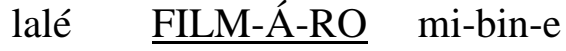
mæmulæn.
Laleh movie-PL-RA DUR-watch.PRS-3SG usually
'Laleh usually watches THE MOVIES.' 


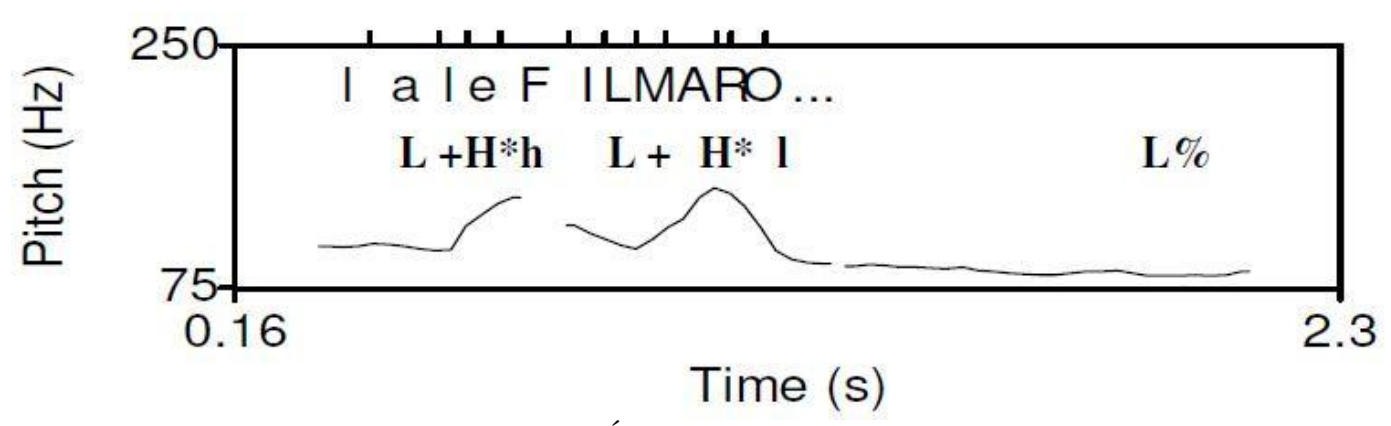

Fig. 17: The contrastive focus utterance lalé FILM-Á-RO mi-bin-e mæemulæen 'Laleh usually watches THE MOVIES.'

The focus mechanism in Persian YNQs is not different from that in declaratives. The focused constituent has an Accentual Phrase of its own causing its following elements to deaccent, and leaving the basic pattern of the interrogative intact. ${ }^{17}$ Consider the sentences in (40) where (40a) is an ordinary YNQ, and (40b) is the same question with the direct object being focused, for instance in a context where the questioner thought at first that the students brought the chairs and now she has heard that it was the tables and not the chairs that they brought and so is asking to confirm. $^{18}$
a. šagerd-á miz-á-ro avórd-æn?
'Did the students bring the tables?' student-PL table-PL-RA bring.PST-3PL
b. šagerd-á MIZ-Á-RO avord-æn? student-PL table-PL-RA bring.PST-3PL 'The students brought THE TABLES?'

The pitch contours of these two sentences are given in Figure 18.

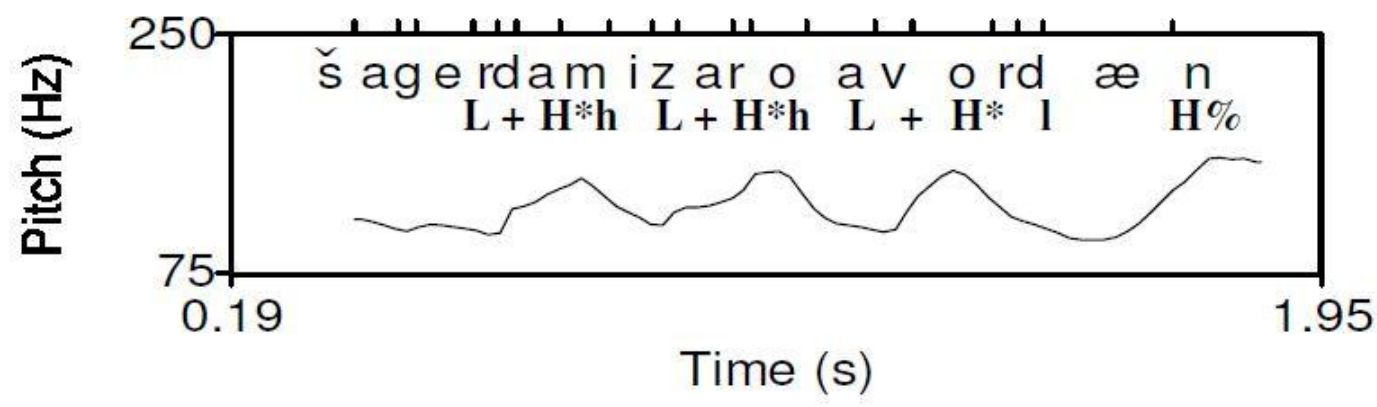

Fig. 18a: The YNQ šagerd-á miz-á-ro avórd-cen 'Did the students bring the tables?'

\footnotetext{
${ }^{17}$ Mandarin shows a similar behavior in which focus produces the same pitch range modification in questions as in declaratives (Liu and Xu 2005).

${ }^{18}$ The term "strongly exhaustive" is sometimes used for questions such as (40b) which have a contrastive presupposition (e.g., Beck and Rullman 1999 and Vergnaud and Zubizarreta 2005).
} 


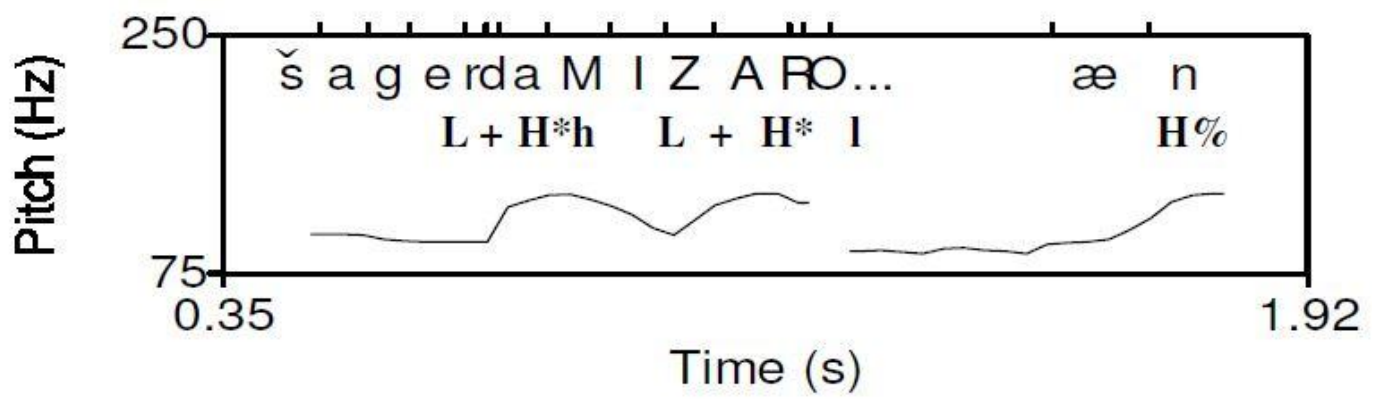

Fig. 18b: The contrastively-focused YNQ šagerd-á MIZ-Á-RO avord- æen 'Did the students bring THE TABLES?'

The focused direct object AP in 18b, i.e., miz-a-ro 'tables', has received a low boundary tone and has deaccented the verb (avord-aen). The focused question ends with an H\%, similar to the nonfocused question.

It was mentioned earlier (Subsection 3.6) that echo YNQs are segmentally and intonationally identical to YNQs with focus. Example (34), an echo YNQ, is repeated here as (41) together with its tonal pattern.

$\begin{array}{llll}\mathrm{L}+\mathrm{H}^{*} \mathrm{~h} & \mathrm{~L}+\mathrm{H}^{*} \mathrm{~h} & \mathrm{~L}+\mathrm{H}^{* 1} & \mathrm{H} \% \\ \text { sayé } & \text { bærá-t } & \underline{\text { mašín }} & \begin{array}{l}\text { xær-id? } \\ \text { Sayeh }\end{array} \\ \begin{array}{l}\text { for-you } \\ \text { 'Sar }\end{array} & \begin{array}{l}\text { buy-PST.3SG } \\ \text { Sayeh bought you a car?' [Echo question] }\end{array}\end{array}$

The intonation of the above echo question is identical to that of the same question when the direct object (mašin 'car') is contrastively-focused. In this sentence, the nuclear accent is on the AP mašin which is realized with a greater excursion and longer duration than the first two APs. ${ }^{19}$

\subsection{Contrastive focus in WHQs}

Any element in Persian WHQs can be focused, i.e., elements to the right of the WH-word, those to its left, and also the WH-word itself (of course with the exception of postverbal words, as stated before). Consider Example (42).

$$
\begin{aligned}
& \text { bæčče-ha æz koja ketab xær-id-æn? } \\
& \text { child-PL from where book buy-PST-3PL } \\
& \text { 'Where did the children buy books from?' }
\end{aligned}
$$

Example (42) is an ordinary WHQ with the WH-word koja 'where' occurring sentence medially. Two focused versions of this WHQ are given in (43). The first has the focus on an item preceding the WH-word (boečce-ha 'children') and the second on an item following it (ketab 'book').

$$
\begin{aligned}
& \text { a. BÆČČE-HÁ æz koja ketab xær-id-æn? } \\
& \text { child-PL from where book buy-PST-3PL } \\
& \text { 'Where did THE CHILDREN buy books from?' }
\end{aligned}
$$

\footnotetext{
${ }^{19}$ The echo YNQ in (41) also has a less common pronunciation with a high AP boundary tone on the direct object. This pronunciation adds to the degree of surprise in the question.
} 
$\begin{array}{lllll}\text { b. bæčče-há } & \text { æz } & \text { kojá } & \text { KETÁB } & \text { xær-id-æn? } \\ \text { child-PL } & \text { from } & \text { where } & \text { book } & \text { buy-PST-3PL }\end{array}$

'Where did the children buy BOOKS from?'

The pitch contours of (43) a and $b$ are provided in Figures 19a and $b$.

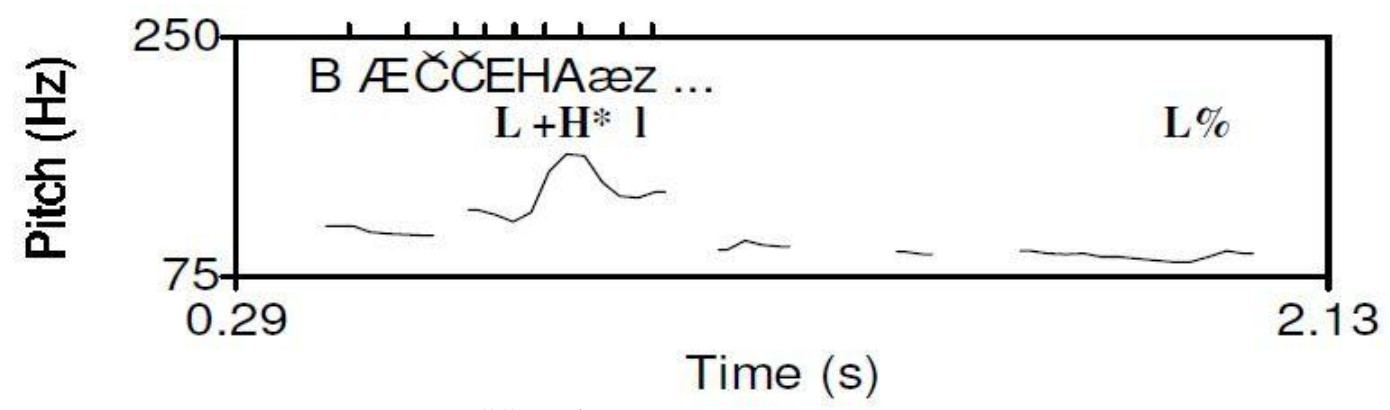

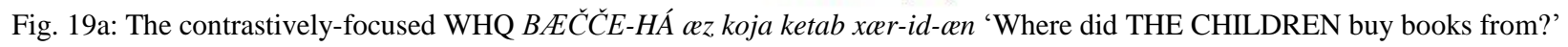

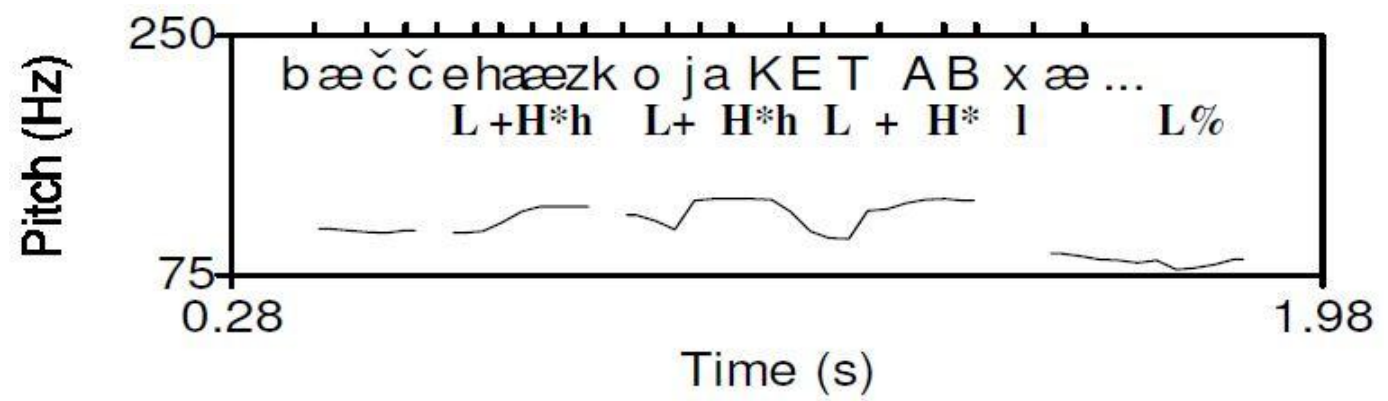

Fig. 19b: The contrastively-focused WHQ bæčče-há azz kojá KETÁB xar-id-an 'Where did the children buy BOOKS from?'

Here is the intonational analysis. In the presence of a focused item, a WH-word acts like an ordinary AP: if the focus precedes the question word, the question word undergoes the normal deaccenting common to postfocal elements; if the focus follows the question word, the question word is realized as a normal $(\mathrm{L}+) \mathrm{H}^{*}$ Accentual Phrase without causing any deaccentuation ${ }^{20}$ So the deaccentuation of focus has priority over the deaccentuation of the WH-word. Figure 19a has the subject baečce- $h a$ focused and as a result, it has formed the only Accentual Phrase of the utterance and everything following it bears its spread low AP boundary tone. In Figure 19b where the focus is on the direct object ketab, the WH-word is an AP with the pattern $\mathrm{L}+\mathrm{H}^{*}$ and a high AP boundary tone since it is not the nuclear pitch accent. The focused AP (ketab) attracts the prominence, gets a low AP boundary tone, and deaccents the verb. Both utterances end with an $\mathrm{L} \%$ as is the common Intonational Phrase boundary tone for WHQs.

The analysis proposed here differs from Mahjani's (2003). He believes that when there are a $\mathrm{WH}$-word and a focus in a sentence, whichever comes later will cancel the deaccenting effect of the other one (in the present analysis, a WH-word to the right of a focus word does not cause this cancellation). The example he gives is (44).

\section{(44) BABÆK-O koja šoma bord-id?}

\footnotetext{
${ }^{20}$ Unlike in Persian, in Romanian, a focused word following the WH-word may deaccent the WH-word (DascăluJinga 1998).
} 
Babak-RA where you take.PST-2PL

'Where did you take BABAK to?'

[Mahjani 2003:63]

He considers two APs for the utterance, one for BABAEK-O and one for koja 'where'. My recordings of the same utterance always has koja deaccented and so conforms to the claim made in this paper that a postfocal question word acts like an ordinary word and gets deaccented. There is one situation in which koja can get a separate Accentual Phrase and that is when $B A B A E K-O$ is pronounced as a separate IP followed by an amount of pause, which is a marked pronunciation. In this case, the focus deaccentuation of $B A B A E K-O$ only extends to the end of the first IP, and koja, being in another IP, retains its pitch accent. So we can consider two different patterns for the sentence in (44), given below in (45).

$\begin{array}{lllll} & \frac{B A B Æ K-O}{L+H^{*} 1} & \text { koja } & \text { šoma } & \text { bord-id? } \\ \text { a. } & & & \mathrm{L} \% \\ \text { b. } & \mathrm{L}+\mathrm{H}^{* 1 \mathrm{~L}} \% & \mathrm{~L}+\mathrm{H}^{* 1} & & \mathrm{~L} \%\end{array}$

The first pattern (45a), where there is one IP and deaccentuation for the question word, corresponds to my analysis, and the second (45b) with two IPs and the question word being assigned an AP matches Mahjani's analysis.

It was mentioned in Subsection 3.4 that WH-words show a pitch increase on $\mathrm{H}$, which together with their deaccenting capability gives them the qualities of a focused constituent. However, in Persian the WH-word can be contrastively-focused itself. ${ }^{21}$ Consider the examples in (46) and their contours in Figure 20, which compare an ordinary WHQ with the same question when the WH-word is focused. The context for the focused version can be a situation where the speaker has asked the listener the question in (46a) and the listener has wrongly heard the word $k i$ 'who' as another word, so the speaker has repeated the question with that word focused.

a. emrúz kí umæd-e-bud?

today who come.PST-PTCP-be.PST.3SG

'Who had come today?'

b. emrúz KÍ umæd-e-bud?

'WHO had come today?'

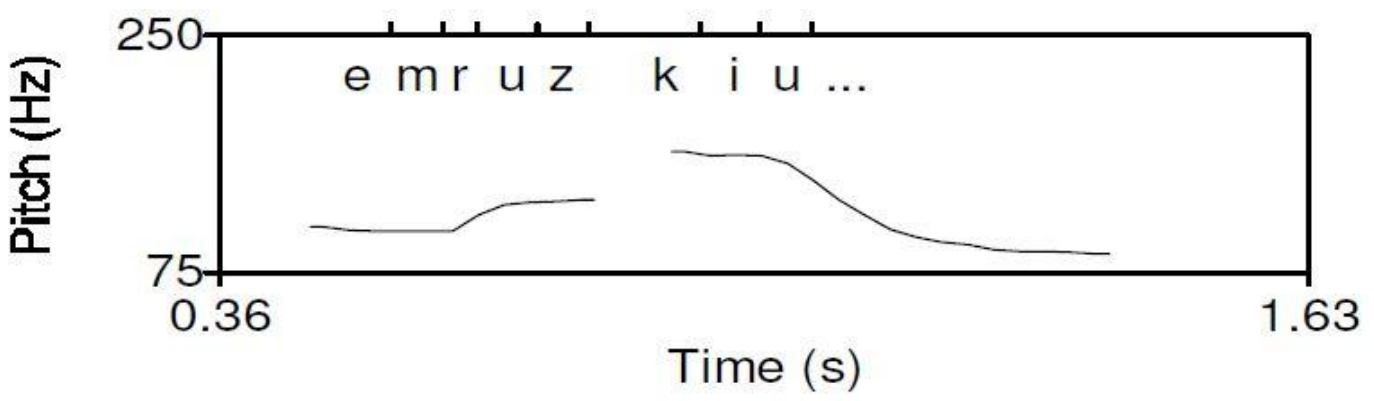

Fig. 20a: The WHQ emrúz kí umaed-e bud 'Who had come today?'

\footnotetext{
${ }^{21}$ This phenomenon is not specific to Persian. For instance, in English, WHEN did you see them? puts when in contrast with other WH-words such as why or where; or in the French sentence QUI va a te rencontrer? 'WHO is going to meet you?', qui 'who' is focalized (and is analyzed as an autonomous intonation unit) (Di Cristo 1998).
} 


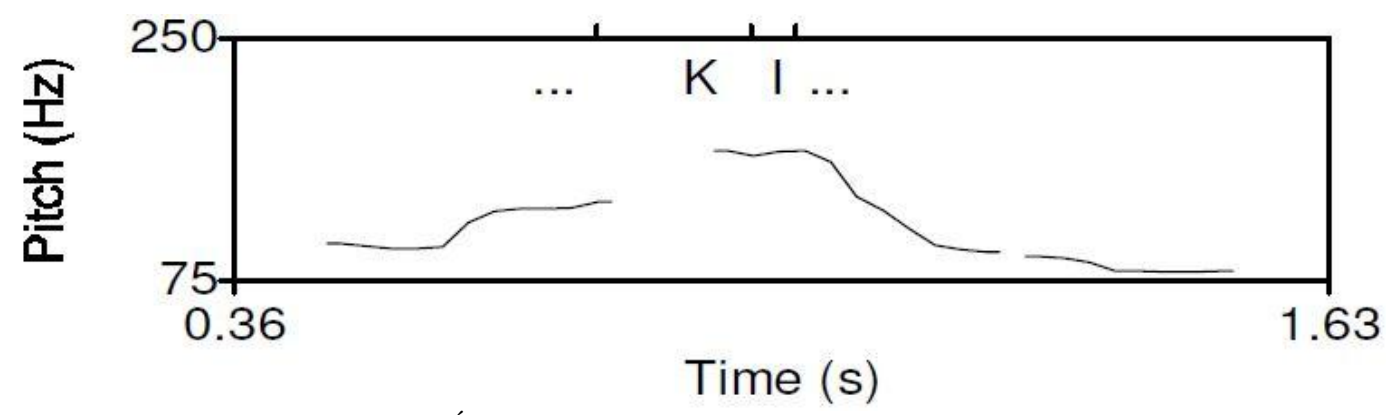

Fig. 20b: The WHQ emrúz KÍ umaed-e bud 'WHO had come today?', with the WH-word focused.

As can be seen, the two utterances are intonationally different. The focused version has a higher pitch on the WH-word than the nonfocused counterpart. Also, this version involves more deaccenting and is overall longer. Thus, WH-words, although exhibiting some characteristics of focus in Persian, are not focus constituents themselves. They are, however, the NPA of an ordinary WHQ due to the fact that they have the most amount of information in the sentence.

To sum up, the contrastively-focused element in interrogatives forms its own Accentual Phrase and becomes the nuclear pitch accent of the utterance and causes deaccentuation in the following elements. The existence of focus in YNQs turns the interrogative into an echo question. In WHQs, focus deaccentuation supersedes WH-word deaccentuation in the sense that a focused AP located to the left of a WH-word deaccents the latter (except when the focused element is in a separate IP), but a WH-word preceding the focus does not cause any deaccentuation.

\section{Conclusion}

This paper investigated the intonation patterns of different types of interrogatives in Persian. In all of the question types studied, the basic element of the Persian intonation system, i.e., the Accentual Phrase with the pitch accent $(\mathrm{L}+) \mathrm{H}^{*}$, is observed. YNQs are phonologically similar to their declarative counterpart in that they consist of one or more APs and the last AP is nuclear. The tonal difference between the two is that the Intonational Phrase boundary tone in YNQs is high as opposed to low in declaratives. The contour of YNQs is different from that of declaratives in certain phonetic respects. First, there is more pitch excursion on the APs especially the last one, second, YNQs have an overall higher register, that is, they occupy higher frequencies along the pitch axis, and third, there is final lengthening on the final vowel. In those YNQs where the IP ends with the stressed syllable of the nuclear AP, the low boundary tone of this AP does not have a docking site and hence is not realized. The interrogative particle aya, which is mostly used in formal style, adds an AP to the pattern without affecting it otherwise. Leading YNQs use the particle moege which can be realized as a separate AP or can become part of the following AP. The existence of this particle results in the utterance having a declarative intonation. However, the speaker can use a YNQ intonation with this particle which signals some degree of surprise. The adverb hic 'nothing', which is used in some YNQs to convey more emphasis, only adds another AP to the intonation of the utterance. Questions with a tag ending contain two IPs, one for the pretag part and one for the tag. The former has a declarative intonation and the latter a YNQ intonation. The intonation of echo YNQs is identical to that of contrastive focus YNQs. 
WHQs have a falling intonation, similar to declaratives. The WH-word, which is the NPA of the utterance and which triggers deaccentuation, is usually pronounced with a pitch increase. In the case of a question having more than one WH-word, the last one is the NPA and the previous ones behave like ordinary APs. Echo WHQs end on a high IP boundary tone. The boundary tone of the final AP in these interrogatives can be either high or low.

A contrastively-focused element in an interrogative forms its own AP with a low boundary tone and causes the deaccentuation of the following elements. Focused APs are realized with a greater pitch excursion and more length. Any element in an interrogative can be contrastivelyfocused. In WHQs, the deaccentuation of focus has priority over that of the WH-word. So if a WH-word is located to the right of focus, it loses its AP status and becomes deaccented, whereas if it precedes focus, it is pronounced like an ordinary AP without causing any deaccentuation.

Table 1 below contains a summary of the structures discussed and their intonational properties.

\begin{tabular}{|c|c|c|}
\hline Structure & Intonation pattern/Phrasing & $\underline{\text { Nuclear pitch accent }}$ \\
\hline Declaratives & \multicolumn{2}{|l|}{$\left(\left((\mathrm{L}+) \mathrm{H}^{*} \mathrm{~h}\right)^{\mathrm{n}} \quad(\mathrm{L}+) \mathrm{H} * 1 \quad \mathrm{~L} \% \quad \mathrm{n}=0,1,2, \ldots\right.$} \\
\hline \multicolumn{3}{|l|}{ Interrogatives } \\
\hline - YNQs & $\begin{array}{l}\text { ((L+)H*h })^{\mathrm{n}}(\mathrm{L}+) \mathrm{H}^{* 1} \mathrm{H} \% \mathrm{n}=0,1,2, \ldots \\
\text { Greater pitch excursion, pitch register, } \\
\text { and final lengthening, and less } \\
\text { declination than declaratives }\end{array}$ & $\begin{array}{c}\text { Copulars: on final element of } \\
\text { complement } \\
\text { SVs: Unergatives: on V } \\
\text { Unaccusatives: } \\
\text { on V, if } \mathrm{S} \text { is specific; } \\
\text { on } \mathrm{S} \text {, if } \mathrm{S} \text { is nonspecific } \\
\text { SOVs: on V, if O is specific; } \\
\text { on O, if } \mathrm{O} \text { is } \\
\text { nonspecific } \\
\end{array}$ \\
\hline The particle $a y a$ & Adds an AP & No change \\
\hline The particle hič & Adds an AP & No change \\
\hline $\begin{array}{l}\text { The particle mage } \\
\text { (Leading YNQs) }\end{array}$ & $\begin{array}{l}\text { Can add an AP, } \\
\text { Declarative } \text { or } \mathrm{YNQ} \text { intonation }\end{array}$ & No change \\
\hline - Tag questions & $\begin{array}{l}\text { Two IPs: } \\
\text { Pretag: Declarative intonation } \\
\text { Tag: YNQ intonation }\end{array}$ & Two NPAs, one in each IP \\
\hline - WHQs & $\begin{array}{l}\text { Declarative intonation; pitch increase on } \\
\text { the WH-word }\end{array}$ & $\begin{array}{l}\text { On WH-word (final WH-word } \\
\text { in multiple WHQs) }\end{array}$ \\
\hline Adv./motions & Declarative intonation & On adverbial \\
\hline The particle mage & Can add an AP & On WH-word \\
\hline "- Echo WHQs & $\begin{array}{ll}\left((\mathrm{L}+) \mathrm{H}^{*} \mathrm{~h}\right)^{\mathrm{n}} \mathrm{H} \% & \mathrm{n}=1,2,3, \ldots \text { or } \\
\text { YNQ intonation } & \\
\end{array}$ & "On WH-word \\
\hline Contrastive focus & $\begin{array}{l}\text { Greater pitch excursion and more length } \\
\text { on the focus AP }\end{array}$ & \\
\hline - YNQs & YNQ intonation & On the focused element \\
\hline - WHQs & WHQ intonation & $\begin{array}{l}\text { On the focused element } \\
\text { (deaccentuation of the } \\
\text { following WH-word(s)) }\end{array}$ \\
\hline
\end{tabular}

Table 1: Summary of structures and their intonational properties. 


\section{References}

Arvaniti, Amalia, D. Robert Ladd, and Ineke Mennen. 2006. Phonetic effects of focus and "tonal crowding" in intonation: Evidence from Greek polar questions. Speech Communications 48.667-696.

Asu, Eva Liina. 2002. Downtrends in different types of questions in Estonian. In B. Bel and I. Marlien (eds.), Proceedings of Speech Prosody 2002 Conference, Aix-en-Provence, France, 143-146.

Atterer, Michaela and D. Robert Ladd. 2004. On the phonetics and phonology of "segmental anchoring" of F0: Evidence from German. Journal of Phonetics 32.177-197.

Avesani, Cinzia. 1995. ToBIt. Un sistema di transcrizione per l'intonazione italiana. In G. Lazzari (ed.), Atti delle V giornate di Studio del Gruppo di Fonetica Sperimentale. Trento: Tipografia Esagrafica, 85-98.

Bateni, Mohammad Reza. 1969. Tosif-e saxteman-e dæsturi-ye zæban-e farsi [A description of Persian syntactic structure]. Tehran: Amir Kabir.

Beck, Sigrid and Hotze Rullmann. 1999. A flexible approach to exhaustivity in questions. Natural Language Semantics 7.249-98.

Beckman, Mary E. and Janet B. Pierrehumbert. 1986. Intonational structure in English and Japanese. Phonology Yearbook 3.255-310.

Boersma, Paul and David Weenink. 2010. Praat: Doing phonetics by computer [Computer program]. Version 5.1.41, retrieved from: http://www.praat.org/

Bolinger, Dwight. 1978. Intonation across languages. In J.P. Greenberg, C.A. Ferguson, and E.A. Moravcsik (eds.), Universals of human language. Volume 2: Phonology. Stanford: Stanford University Press.

Bruce, Gösta. 1977. Swedish word accents in sentence perspective. Lund: Gleerup.

Byrd, Dani. 1992. Pitch and duration in yes-no questions in Nchufie. Journal of the International Phonetic Association. 22.12-26.

Chen, Chun-Mei. 2010. Typology of Paiwan interrogative prosody. Speech Prosody 2010 100376.1-4.

Cruttenden, Alan. 1997. Intonation, second ed. Cambridge: CUP.

-----. 2006. The deaccenting of given information: A cognitive universal? In G. Bernini, and M.L. Schwartz (eds.), The pragmatic organization of discourse in the languages of Europe. The Hague: Mouton de Gruyter, 311-356.

Dabir-Moghaddam, Mohammad. 1982. Syntax and semantics of causative constructions in Persian. PhD thesis, University of Illinois, Urbana.

----- 1992. On the (in)dependence of syntax and pragmatics: Evidence from the postposition -ra in Persian. In D. Stein (ed.), Cooperating with written texts. Berlin: Mouton de Gruyter, 549573.

----. 1997. Compound verbs in Persian. Studies in the Linguistic Sciences 27.25-59.

Dascălu-Jinga, Laurentia. 1998. Intonation in Romanian. In D. Hirst and A. Di Cristo (eds.), Intonation systems: A survey of twenty languages. Cambridge: CUP, 239-260.

Di Cristo, Albert. 1998. Intonation in French. In D. Hirst and A. Di Cristo (eds.), Intonation systems: A survey of twenty languages. Cambridge: CUP, 195-218. 
Eslami, Moharram. 2000. Šenaxt-e næva-ye goftar-e zæban-e farsi væ karbord-e an dær bazsazi væ bazšenasi-ye rayane'i-ye goftar [The Prosody of the Persian ;anguage and its application in computer-aided speech recognition]. PhD thesis, Tehran University.

Eslami, Moharram and Mahmoud Bijankhan. 2002. Nezam-e ahæng-e zæban-e farsi [Persian intonation system]. Iranian Journal of Linguistics 34.36-61.

Esposito, Christina M. and Patrick Barjam. 2007. The intonation of questions in Farsi. UCLA working papers in phonetics 105.1-18, retrieved from: http://www.linguistics.ucla.edu/faciliti/workpapph/105/1Esposito\%20Barjam\%20Farsi\%20Q \%20Intonation.pdf

Folli, Rafaella, Heidi Harley, and Simin Karimi. 2005. Determinants of event type in Persian complex predicates. Lingua 115/10.1365-1401.

Frota, Sónia. 2002a. Tonal association and target alignment in European Portuguese nuclear falls. In C. Gussenhoven and N. Warner (eds.), Papers in Laboratory Phonology VII. Berlin: Mouton de Gruyter, 387-418.

-----. 2002b. Nuclear falls and rises in European Portuguese: A phonological analysis of declarative and question intonation. Probus 14.113-146.

Ghomeshi, Jila. 1997a. Nonprojecting nouns and the Ezafe construction in Persian. Natural Language and Linguistic Theory 15/4.729-788.

----. 1997b. Topics in Persian VPs. Lingua 102.133-167.

Ghomeshi, Jila and Diane Massam. 1994. Lexical/Syntactic relations without projection. Linguistic Analysis 24.175-217.

Grabe, Esther. 1998. Comparative intonational phonology: English and German. Nijmegen: Max Planck Institute.

Grabe, Esther, Greg Kochanski, and John Coleman. 2005. Quantitative modeling of intonational variation. Proceedings of Speech Analysis and Recognition in Technology, Linguistics and Medicine 2003.

Grice, Martine, D. Robert Ladd, and Amalia Arvaniti. 2000. On the place of phrase accents in intonational phonology. Phonology 17.143-185.

Grice, Martine and Michelina Savino. 2003. Map tasks in Italian: Asking questions about given, accessible and new information. Catalan journal of linguistics 2.153-180.

Grice, Martine, Michelina Savino, and Mario Refice. 1997. The intonation of questions in Bari Italian: Do speakers replicate their spontaneous speech when reading? Phonus 3.1-7.

Gussenhoven, Carlos. 2004. The phonology of tone and intonation. Cambridge: CUP.

-----. 2007. Types of focus in English. In D. Büring, M. Gordon, and C. Lee (eds.), Topic and focus: Cross-linguistic perspectives on meaning and intonation. Heidelberg/NY/London: Springer, 83-100.

Haan, Judith. 2002. Speaking of questions. Utrecht: LOT.

Hayes, Bruce and Aditi Lahiri. 1991. Durationally specified intonation in English and Bengali. In J. Sundberg, L. Nord, and R. Carlson (eds.), Music, language, speech, and brain. London: Macmillan, 78-91.

Hedberg, Nancy, Juan M. Sosa, and Emrah Görgülü. 2008. In P.A. Barbosa, S. Madureira, and C. Reis (eds.), Proceedings of Speech Prosody 2008 Conference, Campinas, Brazil, 229-232.

Hedberg, Nancy, Juan M. Sosa, Emrah Görgülü, and Morgan Mameni. 2010. Speech Prosody 2010 100045.1-4.

Hirschberg, Julia. 2002. Communication and prosody: Functional aspects of prosody. Speech Communication 36.31-43. 
Hirst, Daniel, Albert Di Cristo. 1998. A survey of intonation systems. In D. Hirst and A. Di Cristo (eds.), Intonation systems: A survey of twenty languages. Cambridge: CUP, 1-44.

Jun, Sun-Ah. 2005. Prosodic typology. In S.-A. Jun (ed.), Prosodic typology: The phonology of intonation and phrasing. Oxford: OUP, 430-458.

Jun, Sun-Ah, Rebecca Scarborough, Timothy Arbisi-Kelm, Christina M. Esposito, and Patrick Barjam. 2003. Intonational phonology of Farsi. Ms, UCLA.

Kahnemuyipour, Arsalan. 2003. Syntactic categories and Persian stress. Natural Language and Linguistic Theory 21/2.333-379.

-----. 2009. The syntax of sentential stress. Oxford: OUP.

Karimi, Simin. 1996. Case and specificity: Persian ra revisited. Linguistic Analysis 26(3/4).173194.

-----. 2003. On object positions, specificity and scrambling in Persian. In S. Karimi (ed.), Word order and scrambling. Oxford/Berlin: Blackwell, 91-124.

-----. 2005. A minimalist approach to scrambling: Evidence from Persian. Berlin/New York: Mouton de Gruyter.

Keane, Elinor. 2006. Phonetics vs. phonology in Tamil wh-questions. In R. Hoffmann and H. Mixdorff (eds.), Proceedings of Speech Prosody 2006 Conference, paper 002.

Khanlari, Parviz N. 2001. Dæstur-e zæban-e farsi [The grammar of Persian], eighteenth ed. Tehran: Toos.

Kiss, Katalin É. 1998. Identificational focus vs. information focus. Language 74.245-273.

Krahmer, Emiel and Marc Swerts. 2001. On the alleged existence of contrastive accents. Speech Communication 34.391-405.

Ladd, D. Robert. 1980. The structure of intonational meaning: Evidence from English. Bloomington: Indiana University Press.

----. 1996. Intonational phonology. Cambridge: CUP.

-----. 2008. Intonational phonology, second ed. Cambridge: CUP.

Larson, Richard and Hiroko Yamakido. 2005. Ezafe and the deep positions of nominal modifiers. Paper presented at Barcelona Workshop on Adjectives and Adverbs, Barcelona.

Lazard, Gilbert. 1992. A grammar of contemporary Persian. English translation. Costa Mesa, California: Mazda. (Translated from French by Shirley Lyons; first published in 1957 as Grammaire du persan contemporain, Paris, Klinksieck.)

Lee, Hye-Sook. 2008. Non-rising questions in North Kyeongsang Korean. In P.A. Barbosa, S. Madureira, and C. Reis (eds.), Proceedings of Speech Prosody 2008 Conference, Campinas, Brazil, 241-244.

Lee, Ok Joo. 2005. The prosody of questions in Beijing Mandarin. PhD thesis, Ohio State University.

Lickley, Robin J., Astrid Schepman, and D. Robert Ladd. 2005. Alignment of "phrase accent" lows in Dutch falling-rising questions: Theoretical and methodological implications. Language and Speech 48/2.157-183.

Liu, Fang and Yi Xu. 2005. Parallel encoding of focus and interrogative meaning in Mandarin intonation. Phonetica 62.70-87.

Mahjani, Behzad. 2003. An instrumental study of prosodic features and intonation in Modern Farsi (Persian). MS thesis, retrieved http://www.ling.ed.ac.uk/teaching/postgrad/mscslp/archive/dissertations/20023/behzad_mahj ani.pdf

Mahootian, Shahrzad. 1997. Persian. Descriptive Grammars. London: Routledge. 
Ortifelli, Robyn and Kristine Yu. 2009. The intonational phonology of Samoan. Proceedings of AFLA 16. UC Santa Cruz.

Parmoon, Yadollah. 2006. Yek ælgoritm-e æruzi bæra-ye tækiye-ye pišro-ye kæleme dær farsiye emruz [A prosodic algorithm for progressive lexical stress in modern Persian]. In M. Bijankhan (ed.), Proceedings of the $2^{\text {nd }}$ Workshop on the Persian Language and Computer, June 2006, Tehran, 262-284.

Pierrehumbert, Janet B. 1980. The phonology and phonetics of English intonation. PhD thesis, MIT, published 1988 by Indiana University Linguistics Club.

Pierrehumbert, Janet B. and Mary E. Beckman. 1988. Japanese tone structure. Cambridge, Massachusetts: MIT Press.

Prieto, Pilar and Gemma Rigau. 2007. The syntax-prosody interface: Catalan interrogative sentences headed by que. Journal of Portuguese Linguistics 6/2.29-59.

Prieto, Pilar, Jan van Santen, and Julia Hirschberg. 1995. Tonal alignment patterns in Spanish. Journal of Phonetics 23.429-451.

Raghibdust, Shahla. 1994. Multiple wh-fronting in Persian. Cahiers de Languistique 21.27-58.

Rezai, Vali. 2003. Karbordšenasi-ye jomle-ha-ye porseši dær zæban-e farsi [The pragmatics of interrogative sentences in Persian]. Iranian Journal of Linguistics 36.59-78.

Rialland, Annie. 2007. Question prosody: An African perspective. In C. Gussenhoven and T. Riad (eds.), Tones and tunes: Studies in word and sentence prosody. Berlin: Mouton de Gruyter, 35-62.

Rizzi, Luigi. 1997. The fine structure of the left periphery. In L. Haegeman (ed.), Elements of grammar. Drodrecht: Kluwer, 281-337.

Sadat-Tehrani, Nima. 2007. The Intonational grammar of Persian. PhD thesis, University of Manitoba.

-----. 2008. An intonational construction. Constructions 3/2008.1-13.

-----. 2009. The alignment of $\mathrm{L}+\mathrm{H}^{*}$ pitch accents in Persian intonation. The Journal of the International Phonetic Association 39/2.205-230.

Sadeghi, Ali Ashraf and Gholamreza Arjang. 1986. Dæstur-e zæban-e farsi [Persian Grammar]. Tehran: Ministry of Education.

Same'i, Hossein. 1996. Tekye-ye fe'l dær zæban-e farsi: Yek bærræsi-ye mojæddæd [Verb stress in Persian: A reexamination]. The Quarterly Journal of Iranian Academy of Persian Language and Literature 1/4.6-21.

Samiian, Vida. 1994. The Ezafe construction: Some implications for the theory of X-bar syntax. In M. Marashi (ed.), Persian Studies in North America. Maryland: Iranbooks, 17-41.

Samvelian, Pollet. 2007. A phrasal affix analysis of the Persian Ezafe. Journal of Linguistics 43/3.605-645.

Selkirk, Elisabeth. 2002. Contrastive FOCUS vs. presentational focus: Prosodic evidence from right node raising in English. In B. Bel and I. Marlien (eds.), Proceedings of Speech Prosody 2002 Conference, Aix-en-Provence, France, 643-646.

Sosa, Juan M. 1999. La entonacion del Espñol. Su estructura fónica, variabilidad y dialectologia. Madrid: Cátedra.

Tottie, Gunnel and Sebastian Hoffman. 2006. Tag questions in British and American English. Linguistics 34/4.283-311.

Vahidian-Kamyar, Taghi. 2001. Næva-ye goftar dær farsi [Melody of speech in Persian]. Mashhad: Ferdowsi University Press. 
Van Heuven, Vincent and Judith Haan. 2000. Phonetic correlates of statement versus question intonation in Dutch. In A. Botinis (ed.), Intonation. Analysis, modelling and technology. Dordrecht: Kluwer Academic Publishers, 119-143.

Venditti, Jennifer, Sun-Ah Jun, and Mary E. Beckman. 1996. Prosodic cues to syntactic and other linguistic structures in Japanese, Korean, and English. In J. Morgan and K. Demuth (eds.), Signal to syntax: Bootstrapping from speech to grammar in early acquisition. Mahwah, NJ: Lawrence Earlbaum Associates, 287-311.

Vergnaud, Jean-Roger and María-Luisa Zubizarreta. 2005. The representation of focus and its implications: Towards an alternative account of some 'intervention effects'. In H.N. Corver, R. Huybregts, U. Kleinhenz, and J. Koster (eds.), Organizing grammar. Linguistic studies in honor of Henk van Riemsdijk. Berlin/New York: Mouton de Gruyter.

Welby, Pauline. 2006. French intonational structure: Evidence from tonal alignment. Journal of Phonetics 34.343-371.

Xu, Yi. 2010. In defense of lab speech. Journal of Phonetics 38.329-336.

Zeng, Xiao Li, Philippe Martin, and Georges Boulakia. 2004. Tones and intonation in declarative and interrogative sentences in Mandarin. Proceedings of The International Symposium on Tonal Aspects of Languages (with Emphasis on Tone Languages), Beijing, March 2004, 235-238.

Zubizarreta, María-Luisa. 1998. Prosody, focus, and word order. Cambridge, MA: CUP.

Author's Contact Information:

Nima Sadat-Tehrani

University of Manitoba

Winnipeg, Manitoba

Canada R3T 5V5

nisate@yahoo.com 